\title{
Estimating Taxable Income Responses using Danish Tax Reforms*
}

\author{
Henrik Jacobsen Kleven \\ London School of Economics
}

Esben Anton Schultz

Copenhagen Business School and CEBR

\footnotetext{
* We would like to thank Raj Chetty, John Friedman, Hilary Hoynes, Niels Johannesen, Wojciech Kopczuk, Claus Kreiner, Tore Olsen, Emmanuel Saez, Monica Singhal, and Joel Slemrod for helpful suggestions and discussions. We are extremely grateful to the Centre for Applied Microeconometrics (CAM) at the University of Copenhagen for data access, and to the Tuborg Foundation and the Economic Policy Research Network (EPRN) for financial support. Corresponding author: Henrik Kleven, Department of Economics, London School of Economics and Political Science, Houghton Street, London WC2A 2AE, United Kingdom.

E-mail: h.j.kleven@lse.ac.uk
} 


\begin{abstract}
This paper presents evidence on taxable income responses using administrative data that link tax return information to detailed socioeconomic information for the full Danish population over 25 years. The identifying variation is provided by a series of tax reforms that create large tax variation across individuals, income forms, and over time. It is argued that the unique tax variation and data in Denmark makes it possible to control for the biases from non-tax changes in the income distribution and mean reversion that plague much of the existing literature. Using a very large and salient tax reform in the 1980s, we present compelling graphical evidence of taxable income responses by comparing treatment and control groups that experience very similar pre-reform income trends but face very different tax rate changes due to the reform. We then turn to panel regressions using the full population and all reforms over time, which produces the following main findings: (i) Labor income elasticities are modest overall, around 0.05 for wage earners and 0.10 for self-employed individuals. (ii ) Capital income elasticities are two-three times larger than labor income elasticities. (iii) Behavioral elasticities are much larger when estimated from large tax reform changes than from small tax reform changes, consistent with the idea that responses to small tax changes are attenuated by optimization frictions such as adjustment costs and inattention. (iv) Cross-tax effects between labor and capital incomefor example due to income shifting-are in general small. (v) All of our findings are extremely robust to specification (such as pre-reform income controls), suggesting that we have controlled in a sufficiently rich way for non-tax factors impacting on taxable income.
\end{abstract}

JEL Classification Codes: H24; H31; J22. 


\section{Public Economics Programme}

The Public Economics Programme was established in 2009. It is located within the Suntory and Toyota International Centres for Economics and Related Disciplines (STICERD) at the London School of Economics and Political Science. The programme is directed by Frank Cowell and Henrik Kleven. The Discussion Paper series is available free of charge. To subscribe to the PEP paper series, or for further information on the work of the Programme, please contact our Research Secretary, Leila Alberici on:

Telephone: UK+20 79556674

Fax: $\quad$ UK+20 79556951

Email: $\quad$ l.alberici@lse.ac.uk

Web site: $\quad \underline{\text { http://sticerd.lse.ac.uk/PEP }}$ 


\section{Introduction}

The recent literature on behavioral responses to taxation has shifted its focus from the elasticity of hours worked to the elasticity of reported taxable income. Effects on taxable income capture the full range of responses to taxation, including hours worked, unobserved effort, training, occupational choice, tax avoidance and tax evasion, and therefore provides a more complete picture of the behavioral response to taxation. Moreover, as argued by Feldstein $(1995,1999)$ in two influential papers, the elasticity of taxable income provides a sufficient statistic for the revenue and efficiency effect of income taxation, which places this parameter at the centre stage of all the major normative questions in public finance such as the structure of optimal income redistribution and the size of government.

A large and growing literature estimates the elasticity of taxable income using tax return data. Most of this work is based on the United States and uses as its source of identification a series of tax reforms in the 1980s and 1990s that were associated with substantial tax changes at the top of the income distribution (e.g. Feldstein 1995; Auten and Carroll 1999; Moffitt and Wilhelm 2000; Goolsbee 2000; Gruber and Saez 2002; Kopczuk 2005; Giertz 2007). In addition to the U.S. literature, a number of recent studies estimate taxable income responses in other countries that have lowered marginal tax rates at the top of the income distribution through the 1980s and 1990s, including the United Kingdom under the Thatcher administration (Brewer, Saez, and Shephard 2010), Canada (Sillamaa and Veall 2001; Saez and Veall 2005), Norway (Aarbu and Thoresen 2001), and Sweden (e.g. Hansson 2007; Blomquist and Selin 2010; Gelber 2010). ${ }^{1}$

Reforms that strongly target the top of the income distribution provide interesting variation, but are also associated with some important empirical difficulties. Because the allocation of tax treatments is determined by pre-reform income level, we have to consider the possibility that different income groups differ in a number of non-tax dimensions that impact on taxable income

\footnotetext{
${ }^{1}$ Alongside the large literature using income tax reforms to estimate taxable income responses, a recent smaller literature estimates taxable income responses using bunching around kink points created by discrete jumps in the marginal tax rate in piecewise linear income tax schedules (Saez 2010; Kleven et al. 2010; Chetty et al. 2011). While bunching around kink points provides a very compelling source of identification in principle, an important limitation of this strategy is that there tends to be very little bunching in empirical distributions. Only very sharp and salient kinks create any bunching at all, and even there the response is modest (Chetty et al. 2011). The likely explanation is the presence of optimization frictions associated with locating exactly at the cutoff (such as adjustment costs, misperception and inattention) combined with the fact that the utility gain of bunching in response to jumps in marginal tax rates is typically not very large (Chetty 2011).
} 
and are correlated with the tax law changes. This problem is reinforced by the fact that tax return data typically contain very little information about taxpayers besides income variables and tax rates, making it difficult to control for any non-tax differences across different taxpayers.

Two specific problems have been discussed extensively in the literature (e.g. Slemrod 1998; Saez 2004; Saez, Slemrod, and Giertz 2010). First, it is very hard to disentangle tax-driven increases in top incomes from increases that are driven by non-tax factors such as skill-biased technical change and globalization. This problem is particularly important in countries that have experienced strong secular increases in top income shares, and may result in a substantial upward bias in the elasticity estimates. Second, defining treatments and controls according to pre-reform income level creates a mean-reversion problem, because a taxpayer with a positive income shock in the pre-reform year will tend to have a lower income in the following years, independently of the reform. For tax cuts at the top, this biases elasticity estimates downwards. In order to correct for the two biases mentioned above, the literature has attempted to control in a number of ways for pre-reform income levels. However, the richness of such income controls is constrained by the fact that the identification comes from different tax changes across pre-reform income levels, and in general the results turn out to be extremely sensitive to specification.

This paper presents new evidence on taxable income responses based on a series of Danish tax reforms and a very rich administrative dataset covering the entire Danish population over 25 years (1980-2005). The Danish tax context and data holds the promise to avoid the biases discussed above for the following three reasons. First, by linking tax return data to administrative data containing detailed socioeconomic information for every taxpayer, we control directly for some of the underlying non-tax components of permanent and transitory income that are important for the biases discussed above. Second, the evolution of the Danish income distribution has been much more stable than in most other countries, even compared to other egalitarian societies such as Sweden. ${ }^{2}$ To illustrate this, Figure 1 shows top income shares based on a broad income measure including all labor income and capital income. As the figure makes clear, top income shares have been roughly constant over time with the exception of a tiny increase after the mid-1990s. The unchanging income distribution in Denmark isolates mean-reversion as the potential bias that must be controlled for.

\footnotetext{
${ }^{2}$ Atkinson, Piketty and Saez (2011) provide international overviews of the evolution of top income shares, while Roine and Waldenström (2008) study the Swedish experience.
} 
Third, we consider a time period that encompasses a series of tax reforms, which create large and compelling identifying variation. In some years, the tax variation created by the Danish reforms is larger than the variation created by the major U.S. reforms of the 1980s, and importantly the Danish variation does not does not feature the same strong correlation with income level as the U.S. variation. The Danish reforms were associated with three main changes: $(i)$ differential changes in marginal tax rates across different tax brackets, $(i i)$ changes in bracket cutoffs that moved large groups of taxpayers to different brackets, and (iii) a move from a fully symmetric treatment of different income components (e.g. labor income vs. capital income and positive income vs. negative income) to an asymmetric treatment of different income components. The combination of points $(i)$ and $(i i)$ create large and nonlinear tax variation through the income distribution in a way that is not systematically correlated with income level. Point ( $i i i$ ) implies that income composition, besides income level, plays a key role for the tax bill, thereby creating variation across individuals at the same income level. All three changes together therefore create very rich identifying tax variation.

In a tax system based on asymmetric tax treatment of different income forms, estimating the elasticity of overall taxable income with respect to the marginal tax rate is not very meaningful as there is no single well-defined marginal tax rate associated with this income concept. More importantly, the presence of independent tax variation across different income forms provides a rare opportunity to analyze the anatomy of taxable income responses, a question which is interesting in its own right (Slemrod 1995, 1996, 1998; Saez, Slemrod, and Giertz 2010). To explore this, we estimate responses for the underlying components of taxable income separately, and we also consider specifications allowing for cross-tax effects between different income forms.

Our main findings and contributions are the following. First, focusing on a very large and salient tax reform in the 1980s, we present clear graphical evidence of behavioral responses for both labor and capital income. The evolution of labor and capital income in a treatment group (facing large tax cuts) and a control group (facing tax increases) is completely parallel in the pre-reform period and then diverges sharply at the time of the reform. The existing literature on taxable income elasticities has not been able to produce compelling graphical evidence of this sort. A basic difference-in-differences approach using the reform and treatment-control assignment in the graphical analysis produces elasticities in the range of 0.2-0.3. Second, turning to panel regressions using all tax reform variation over a long time period and a rich set of socio- 
economic controls, we find that elasticities are in general quite modest. Labor income elasticities are around 0.05 for wage earners and 0.10 for self-employed individuals, while capital income elasticities tend to be two-three times larger than labor income elasticities. Third, behavioral elasticities (both labor and capital) are substantially larger when estimated from large tax reform episodes than from small tax reform episodes. This finding is consistent with the argument by Chetty et al. (2011) and Chetty (2011) that elasticities estimated from small tax changes are attenuated by optimization frictions (such as adjustment costs and inattention), whereas large tax changes are likely to overcome such frictions and hence reveal the true long-run elasticity. We show that the large tax reform variation in the 1980s is associated with a population-wide elasticity of labor income of about 0.12, whereas the smaller tax reform variation in the 1990s and 2000s is associated with a labor income elasticity of only 0.02. Moreover, zooming in on the very largest tax variation in the 1980s (by considering specific groups and years as in the graphical analysis discussed above) produces even larger elasticities. Fourth, cross-tax effects between labor and capital income are in general weak, with a small degree of complementarity between the two income forms for wage earners and a small degree of substitutability for selfemployed individuals. Since income shifting for tax avoidance purposes by itself would imply substitutability, our results suggest that income shifting is more prevalent for the self-employed than for wage earners.

Finally, we show that the above set of findings is extremely robust to empirical specification, including the specification of pre-reform income controls. We explore the different income controls that have been proposed in the literature along with alternative specifications that control in a richer way for mean reversion. The robustness of our findings is reassuring and suggests that we have controlled in a sufficiently rich way for non-tax factors impacting on taxable income. Against this background, we argue that the Danish context offers a useful laboratory allowing for a credible identification of taxable income responses.

The paper proceeds as follows. Section 2 describes the Danish tax system and tax reforms, while section 3 describes the data. Section 4 sets out the empirical strategy and presents graphical evidence. Section 5 presents empirical results from panel regressions, while section 6 concludes. 


\section{The Danish Tax System and Tax Reforms}

The Danish individual income tax system treats different income forms in a partially separate fashion, as opposed to standard tax systems that apply a progressive rate structure to a single measure of taxable income. The income concepts of the Danish income tax system, shown in Table 1, are given by labor income (LI), personal income (PI $=\mathrm{LI}+$ other PI), capital income exclusive of stock income (CI), stock income (SI), deductions (D), and taxable income (TI = PI $+\mathrm{CI}+\mathrm{SI}-\mathrm{D})$. These income concepts are aggregated into several different tax bases that are taxed at different rates. The definition of those bases as well as the associated tax rates have undergone substantial changes over time due to a series of tax reforms, and this is the variation that we exploit to estimate behavioral elasticities.

Taxes are divided into national taxes and regional taxes at the municipal and county level, but the two types of taxes are enforced and administered in an integrated system. At the national level, a series of important tax acts have been implemented over the past 25 years. Those tax acts are the 1987-reform, the 1994-reform, the 1999-reform (called the "Pentecost Package"), and the 2004-reform (called the "Spring Package"). Most of these reforms were phased in over several years, which generates considerable tax variation in most years of the period we consider. We also exploit changes in tax schedules at the regional level, but those changes have been much smaller and are more uniform across taxpayers than the national changes.

Throughout the period we consider, the national income tax has been divided into three main brackets: a bottom bracket, a middle bracket, and a top bracket. The past 25 years of tax reform have been associated with three main changes. First, a lowering of marginal tax rates in each bracket, with larger cuts in the middle and top brackets than in the bottom bracket. Second, a substantial broadening of the tax base as negative capital income and deductions were prevented from offsetting positive income on a one-to-one basis. This change was implemented by changing the tax schedule from a function of total taxable income (TI) to a function of each of the underlying income components (LI, PI, CI, SI, D), with a higher marginal tax rate on labor income than on the other income components as well as a higher marginal tax on positive income than on negative income (such as mortgage interest and deductions). With the exception of stock income, the taxation of the different income components is not fully separate and cross-effects in the tax function are therefore non-zero. Third, adjustments of bracket cutoffs that did not 
correspond to the base broadening, thereby pushing taxpayers into higher brackets. This bracket push combined with the fact that tax rates were reduced within each bracket imply substantial and very heterogeneous tax rate variation through the income distribution. All of the changes together create strong variation across taxpayers at different income levels, across taxpayers at similar income levels (but different income compositions), and across different income types. Below we describe the tax reforms in greater detail.

Table 2 shows the different tax rates and associated tax bases in four specific years: 1986 (before the 1987-reform), 1993 (before 1994-reform), 1998 (before the 1999-reform), and 2005 (after the 1999- and 2004-reforms). The tax system consists of a flat regional tax (shown for the average municipality) along with progressive national taxes levied on varying tax bases. The main national taxes are the bottom tax, the middle tax and the top tax, and in some years those taxes are supplemented by social security contributions, labor market contributions, and an EITC. The different tax rates shown in the table are cumulative such that a taxpayer in the top bracket is subject to the sum of the bottom, middle, and top taxes (along with the other flat taxes). ${ }^{3}$ The table shows the tax base changes mentioned above. In the mid-1980s, all tax rates applied to overall taxable income, whereas in the 1990s and 2000s no tax rate applies to this broad income measure. In 2005, for example, tax liability is calculated from four different tax bases: taxable income exclusive of stock income $(\mathrm{PI}+\mathrm{CI}-\mathrm{D})$, personal income plus positive net capital income $(\mathrm{PI}+[\mathrm{CI}>0])$, labor income $(\mathrm{LI})$, and stock income (SI).

There are two points to make with regard to those tax base changes. First, in a situation where taxable income include subcomponents that are treated differently, it is not meaningful to estimate an elasticity of overall taxable income with respect to the marginal tax rate as there exists no single, well-defined marginal tax rate for this income concept. We therefore consider the underlying income components of the tax system separately, focusing on labor income and capital income (excluding stock income). We do not consider stock income as it is taxed on a completely separate schedule, which has remained relatively constant throughout most of the

\footnotetext{
${ }^{3}$ For example, in 1986, a taxpayer in the top bracket would face a marginal tax rate equal to $28.1+14.4$ $+14.4+10.8+5.5=73.2 \%$. However, a marginal tax ceiling is in place in all years, and this ceiling equals $73 \%$ in 1986 and is therefore binding for a taxpayer living in an average municipality. In 2005, the marginal tax ceiling has dropped to $59.0 \%$ and was indeed also binding for a taxpayer in the top bracket living in the average municipality. For labor income, there is a labor market contribution of $8 \%$ on top of the tax ceiling, but at the same time labor income enters all the other tax bases net of the labor market contribution. The effective tax ceiling on labor income in 2005 is therefore equal to $8.0+(1-0.08) \times 59.0=62.3 \%$.
} 
period and therefore offers less variation than the rest of the income tax code. ${ }^{4}$ Second, the type of base broadening described above does not raise the conceptual problems that have been discussed extensively in the literature on taxable income responses (Slemrod 1998; Kopczuk 2005). The usual problem is that such reforms require us to consider constant-definition tax bases in order to avoid confounding behavioral and definitional changes, but in so doing we are relating the tax rate to an artificial tax base different from the one in the tax code in a given year. However, the base broadening shown in Table 2 does not pose this problem (and indeed create a lot of interesting variation that we will exploit), because it does not consist in including previously untaxed components in the tax system. In all years, the tax system depends on the same underlying income components, and it is instead the aggregation of those income components into tax bases that changes over time.

Figure 2 illustrates the implications of the tax rate and tax base changes described above for the effective marginal tax rates on labor and capital income in each bracket (bottom, middle, and top) over time. For labor income (Panel A), the marginal tax rate in the top bracket has been declining from $73 \%$ to $62 \%$, while the tax rate in the middle bracket has been declining from $62 \%$ to $49 \%$. On the other hand, the bottom tax rate is increasing over the early part of the period and then declining over the later part of the period. Overall, the difference between the bottom tax and the middle/top taxes has been shrinking over this period, although the relative changes have not been dramatic. However, these graphs do not reveal the important implications of bracket push as we come back to below.

For capital income, we distinguish between negative capital income (Panel B) and positive capital income (Panel C) as the two are taxed very differently. For negative capital income, the three brackets have collapsed into one bracket subject to the bottom tax rate (as negative capital income was excluded from the middle and top tax bases). For taxpayers in the top bracket, the marginal tax rate associated with negative capital income has dropped from about $73 \%$ to $33 \%$ over the period, while for taxpayers at the bottom the drop has been much smaller. These dramatic tax changes affect a very large number of taxpayers, because capital income is in fact negative for the majority of Danish taxpayers as a result of interest payments on loans (mortgage and other loans). For positive capital income, we also see very large changes as the

\footnotetext{
${ }^{4}$ The most useful quasi-experimental variation in stock income taxation is created, not by tax reforms, but by a sharp kink at the cutoff between two brackets in the stock income tax. Kleven et al. (2010) use bunching around this kink to estimate the elasticity of stock income and find evidence of strong behavioral responses.
} 
band between the top and the bottom first narrows substantially (since all capital income is excluded from the top tax base) and then widens substantially (since positive capital income is reintroduced in the top tax base).

Finally, to see the importance of bracket push due to under-adjustment of bracket cutoffs as bases were broadened, Panel D shows the evolution over time in the share of taxpayers located in each bracket. We see that the share of taxpayers liable to pay the top tax has increased dramatically from less than $10 \%$ of the population in the mid-1980s to almost $30 \%$ of the population in the mid-2000s. The share of individuals in the middle bracket has fallen from about $40 \%$ to slightly above $20 \%$ over the whole period, while the share of taxpayers in the bottom bracket falls from about $50 \%$ to $40 \%$ in the early part of the period and then rises back to $50 \%$ in the latter part of the period. ${ }^{5}$ These movements across brackets create substantial tax variation, especially for labor income. The combination of the tax rate changes for labor income in Panel A and the bracket push in Panel D create very strong and heterogeneous tax variation through the income distribution.

Overall, the reforms described in this section implies substantial tax variation over time and across individuals. Indeed, as we show in section 4 when discussing the identification strategy, the variation in some years is comparable to the major tax acts in the U.S. in the 1980s and the Tax Reform of the Century in Sweden in the early 1990s.

\section{Data}

The analysis is based on a very rich panel that runs from 1980 to 2005 and covers the entire universe of Danish taxpayers. The data set has been constructed by Statistics Denmark based on a number of administrative registers, including the Income Tax Register and the Integrated Database for Labor Market Research (IDA). For each individual, the data set contains detailed tax return information along with a large set of socioeconomic variables such as place of residence, gender, age, marital status, number and age of kids, immigrant status, ethnicity, employment status, job experience, education, occupation, and industry.

Marginal tax rates are not directly observed in tax return data, and we therefore have to simulate the marginal tax rate for each taxpayer based on tax return information and a model

\footnotetext{
${ }^{5}$ The bottom, middle, and top bracket shares do not quite add up to 1 , because a small amount of taxpayers below a basic exemption level are not liable to pay the bottom tax.
} 
the Danish tax system. As there exists no publicly available TAXSIM model for Denmark, we have constructed our own TAXSIM model of the Danish tax system over the period 1984-2005. Based on this model and tax return data, we compute the marginal tax rate on a given income component by increasing income by DKK 100 ( $\simeq$ USD 20). In particular, if tax liability $T($. is a function of $n$ different income components $z^{1}, \ldots, z^{n}$, we compute the marginal tax on $z^{j}$ as $\left.\tau^{j}=\left[T\left(z^{1}, \ldots, z^{j}+100, \ldots z^{n}\right)-T\left(z^{1}, \ldots, z^{j}, \ldots z^{n}\right)\right)\right] / 100 .^{6}$

Following Gruber and Saez (2002), the empirical strategy is to relate changes in reported income over time to changes in marginal tax rates over time for individual taxpayers. We focus on the period 1984-2005 and consider three-year intervals (1984-1987, ..., 2002-2005). We denote the first year in any given three-year interval by $s$ and the last year by $s+3$. We include only taxpayers that are also observed in year $s-1$ and $s-2$, because we use those years to construct pre-reform income controls. The three-year differences are stacked to obtain a dataset with about 49 million observations.

We restrict the sample used for estimation in the following ways. First, we restrict the sample to individuals aged 15-70 years. Second, we exclude individuals whose income in base year $s$ comes primarily from welfare benefits, because this would require us to account for the important incentive effects of the welfare system and model extensive responses. Third, we limit our sample to people who are fully tax liable in Denmark. These restrictions leave us with a sample of about 37 million observations. Table 3 shows summary statistics for the estimation sample.

\section{Empirical Strategy and Graphical Evidence}

\subsection{The Model}

The economic model underlying the new tax responsiveness literature is a simple extension of the traditional labor supply model. It is assumed that each taxpayer maximizes a utility function of the form $u(c, z, x)$, where $c$ is consumption, $z$ is reported taxable income, and $x$ is a vector of individual characteristics. We may think of reported income $z$ as being generated by a number of underlying choices such as hours worked, unobserved effort, training, occupational choice, tax

\footnotetext{
${ }^{6}$ While the Danish income tax system is based on individual filing for married couples, it involves certain elements of jointness due to the fact that some exemptions can be transferred across spouses. This implies that, for a married person, income tax liability depends on both individual incomes and on spousal incomes. Our TAXSIM model fully accounts for this jointness.
} 
sheltering activities, etc. The implicit assumption in the literature is therefore that all those underlying activities are weakly separable from consumption in the utility function. Utility is maximized subject to a budget constraint $c=z-T(z)=(1-\tau) \cdot z+y$, where $T($.$) is tax$ liability, $\tau \equiv T^{\prime}$ (.) is the marginal tax rate, and $y \equiv \tau \cdot z-T(z)$ is virtual income. We may then write the optimal choice of taxable income as $z=z(1-\tau, y, x)$.

Consistent with the Danish setting described earlier, we extend the above model to account for the presence of multiple income types that are taxed differently. Consider therefore a consumer choosing incomes $z^{1}, \ldots, z^{n}$ under a tax schedule $T\left(z^{1}, \ldots, z^{n}\right)$. This consumer maximizes utility

$$
u=u\left(c, z^{1}, \ldots, z^{n}, x\right)
$$

subject to a budget constraint

$$
c=\sum_{j=1}^{n} z^{j}-T\left(z^{1}, \ldots, z^{n}\right)=\sum_{j=1}^{n}\left(1-\tau^{j}\right) z^{j}+y,
$$

where $\tau^{j} \equiv \partial T / \partial z^{j}$ is the marginal tax rate on income type $z^{j}$ (which is in general a function of all the different incomes $\left.z^{1}, \ldots, z^{n}\right)$ and $y \equiv \sum_{j=1}^{n} \tau^{j} z^{j}-T\left(z^{1}, \ldots, z^{n}\right)$ is virtual income. Our measure of virtual income is a generalization of standard virtual income to a situation with multidimensional income. As all $z$-variables in eq. (2) are defined as income, if a given component $z^{j}$ reflects a deduction in taxable income, then this component is defined as minus deductions.

In this model, the optimal choice of any given income type $z^{j}$ depends on all the net-of-tax prices and virtual income, i.e.

$$
z^{j}=z^{j}\left(1-\tau^{1}, \ldots, 1-\tau^{n}, y, x\right)
$$

In general, an empirical specification for a given income type $z^{j}$ should account for both ownprice effects of changes in the marginal net-of-tax rate on income $j$ as well as cross-price effects of changes in the net-of-tax rates on all the other income types. Indeed, the Danish tax reforms offer a rare opportunity to identify cross-tax effects between different income forms. In the empirical analysis, we start by considering baseline specifications without cross-tax effects, and then turn to specifications that allow for cross-tax effects. The analysis of cross-tax effects enables us to evaluate the potential importance of income shifting between labor and capital income, an issue that has been much discussed in the literature. 
In the baseline model without cross-tax effects, expression (3) implies $z_{i s}^{j}=z^{j}\left(1-\tau_{i s}^{j}, y_{i s}, x_{i s}\right)$ for taxpayer $i$ at time $s$. Adopting a log-linear specification (as is standard in the literature), we consider the following specification

$$
\log \left(z_{i s}^{j}\right)=\alpha+\varepsilon \cdot \log \left(1-\tau_{i s}^{j}\right)+\eta \cdot \log \left(y_{i s}\right)+\gamma_{s}^{c} \cdot x_{i}^{c}+\gamma^{v} \cdot x_{i s}^{v}+\mu_{i}+\nu_{i s} .
$$

In this specification, we distinguish between time-invariant individual characteristics $x_{i}^{c}$ whose effect may change over time and time-variant individual characteristics $x_{i s}^{v}$ whose effect is constant over time. The effect of time-invariant individual characteristics whose effect is constant over time is subsumed in the individual fixed effect $\mu_{i}$. The key variables of interest are the uncompensated elasticity of reported income $(\varepsilon)$ and the income elasticity $(\eta){ }^{7}$

In first-differenced form, the model can be written as

$$
\Delta \log \left(z_{i s}^{j}\right)=\varepsilon \cdot \Delta \log \left(1-\tau_{i s}^{j}\right)+\eta \cdot \Delta \log \left(y_{i s}\right)+\Delta \gamma_{s}^{c} \cdot x_{i}^{c}+\gamma^{v} \cdot \Delta x_{i s}^{v}+\Delta \nu_{i s} .
$$

In the baseline specification, differences at time $s$ are three-year differences from $s$ to $s+3$.

\subsection{Identification and Relationship to Previous Literature}

Because of the nonlinearity of the tax system, the marginal tax rate and virtual income are endogenous to the choice of taxable income, which creates a correlation between $\Delta \log \left(1-\tau_{s}^{j}\right)$, $\Delta \log \left(y_{s}\right)$, and the error term. The usual way to construct instruments for these variables is to use mechanical tax changes driven by changes in tax laws. Hence, using the Danish TAXSIM model described above, we simulate post-reform marginal tax rates under pre-reform behavior, $\tau_{s+3}^{j}\left(z_{s}^{1}, \ldots, z_{s}^{n}\right)$, where we account for the fact that the marginal tax rate on income $j$ may depend not just on the level of income $j$ but also on the levels of the other incomes. From the simulated marginal tax rates, we obtain mechanical net-of-tax rate changes, $\log \left(1-\tau_{s+3}^{j}\left(z_{s}^{1}, \ldots, z_{s}^{n}\right)\right)-\log \left(1-\tau_{s}^{j}\left(z_{s}^{1}, \ldots, z_{s}^{n}\right)\right)$, which are used as instruments for the observed changes $\Delta \log \left(1-\tau_{s}^{j}\right)$. Analogously, we simulate post-reform virtual incomes under pre-reform behavior, $y_{s+3}\left(z_{s}^{1}, \ldots, z_{s}^{n}\right)=\sum_{j=1}^{N} \tau_{s+3}^{j}\left(z_{s}^{1}, \ldots, z_{s}^{n}\right) z_{s}^{j}-T_{s+3}\left(z_{s}^{1}, \ldots, z_{s}^{n}\right)$, and associated mechanical changes in virtual income, $\log \left(y_{s+3}\left(z_{s}^{1}, \ldots, z_{s}^{n}\right)\right)-\log \left(y_{s}\left(z_{s}^{1}, \ldots, z_{s}^{n}\right)\right)$, which are used as instruments for the observed changes $\Delta \log \left(y_{s}\right)$.

\footnotetext{
${ }^{7}$ The specification of the income effect in terms of virtual income (as defined above) is different from the specification in several previous studies on taxable income elasticities (e.g. Gruber and Saez 2002; Kopczuk 2005), which specifies the income effect simply in terms of after-tax income $z-T(z)$.
} 
While the mechanical tax changes used as instruments are exogenous to post-reform incomes, they do depend on pre-reform incomes. Hence, the instruments may be correlated with the error term if the pre-reform income level is correlated with the error term. The literature has discussed two channels through which this may occur. First, taxpayers at different pre-reform income levels may experience different income trends for non-tax reasons. Indeed, many countries have experienced sharply increasing top income shares over the past few decades, and several studies have argued that these changes are driven by skill-biased demand shocks resulting from innovation and globalization. Unless skill can be directly controlled for, it would be captured by pre-reform income levels and skill-biased changes would then be absorbed in the estimated elasticity. Second, the pre-reform income level reflects both permanent and transitory income components, which creates a mean-reversion problem: a taxpayer with a very high income in the pre-reform year will tend to have a lower income in the post-reform year, other things being equal. In the absence of controls for transitory income components, they would be captured by pre-reform income levels and hence be absorbed by the estimated tax effect.

The problems just described are particularly acute when considering tax reforms that are strongly targeted to certain income groups such as high-income earners (as in the case of the U.S. tax reforms in the 1980s). In that case, the mechanical tax changes will be strongly correlated with income level and therefore with skill-dependent demand shocks and transitory income components. To deal with this problem, Auten and Carroll (1999), Moffitt and Wilhelm (2000), Gruber and Saez (2002), and Kopczuk (2005) propose to control in different ways for pre-reform income. For example, Kopczuk (2005) proposes a specification that includes the change in income in the year prior to the reform, $z_{s}-z_{s-1}$, as a proxy for transitory income components, along with the lagged income level $z_{s-1}$ as a proxy for the permanent income level. He allows for nonlinearity by experimenting with 10-piece splines in the logarithms of either of the two controls. He also explores a number of other specifications, including those adopted by Auten and Carroll (1999) and Gruber and Saez (2002). The results show that the elasticity estimates are extremely sensitive to the specification of pre-reform income controls.

We consider the various income controls that have been proposed in the earlier studies, along with specifications that control in a richer way for the dynamic income process. The rich tax variation in Denmark allows us to include additional lags and higher-order splines without soaking up all the identifying variation. Unlike the previous literature, we find that our results 
are extremely robust to the specification of income controls, suggesting that we have controlled in a sufficiently rich way for non-tax factors impacting on taxable income.

There are three key reasons for the robustness of our findings. First, because of the large set of socioeconomic variables in the data, we are able to control directly for a number of non-tax characteristics driving permanent and transitory income components. For permanent income, variables on education (level attained and area of study) capture skill level, which controls for the effect of a changing income distribution due to skill-biased demand shocks. Variables on gender, marriage, kids, immigration, and ethnicity may further control for permanent income components. For transitory income, controlling for variables such as place of residence, local unemployment, age, job experience, occupation, and industry ensure that we are comparing individuals affected similarly by idiosyncratic labor market conditions, which alleviates the problem of mean-reversion. Second, as discussed in the introduction and shown in Figure 1, there has been no significant secular change in the income distribution in Denmark, implying that the bias from unobserved non-tax factors affecting the income distribution is not a big concern here. This isolates mean-reversion as the potential bias that the income controls have to correct for (to the extent that the other socioeconomic variables are not sufficient). Third and crucially, the biases discussed above rely on the presence of a correlation between tax changes and pre-reform income level, which is not an important feature of the Danish reforms. As described earlier, the Danish reforms were not systematically targeted to certain income groups and created are lot of up-and-down movements in tax rates throughout the income distribution. In fact, the increasing asymmetry in the tax treatment of different income components creates variation even for taxpayers at the same income level (but with different income compositions). In the next section, we demonstrate the exact nature of the Danish variation around specific reform episodes.

\subsection{Mechanical Variation in Marginal Net-of-Tax Rates}

To give a precise sense of the identifying variation, Figures 3-5 show the mechanical variation in marginal net-of-tax rates (i.e., the variation in the instrument) for different income types around the two largest reform episodes in our data, the 1987- and 1994-reforms. Each figure shows three-year differences in percent, where we have split the sample into seven groups using base-year income variables: $(i)$ individuals who are in the bottom bracket both before and after, 
(ii) individuals who are pushed from the middle to the bottom bracket, (iii) individuals who are pushed from the bottom to the middle bracket, $(i v)$ individuals who are in the middle bracket both before and after, $(v)$ individuals who are pushed from the top to the middle bracket, $(v i)$ individuals who are pushed from the middle to the top bracket, and (vii) individuals who are in the top bracket before and after. It is important that the grouping is based only on base-year income variables and therefore does not incorporate a behavioral response.

Before considering the tax variation in Figures 3-5, let us briefly remark on two aspects of the figures. First, it is the combination of changes in tax bases and bracket cutoffs that makes it possible for a tax reform to push some taxpayers from a lower to a higher bracket (e.g. bottom to middle) and simultaneously push other taxpayers in the opposite direction (e.g. middle to bottom). Second, the grouping of taxpayers in the figure is useful to make the identifying tax changes stand out. The grouping is different from one based on quantiles of the income distribution (for e.g. total taxable income). Such a grouping would show much less average tax variation in each quantile group as it lumps together tax reductions for those who stay in a given bracket or move to a lower bracket with tax increases for those who are pushed into a higher bracket. Hence, an income quantile representation of tax changes would hide a lot of the identifying variation in the data.

Each figure shows the sizes of the different groups as a share of all taxpayers (red bars) along with the mechanical changes in the marginal net-of-tax rate in the different groups (blue graph). ${ }^{8}$ Figure 3 illustrates the variation in labor income taxation around the 1987-reform (1986-1989 difference) in Panel A and around the 1994-reform (1993-1996 difference) in Panel B. For the 1987-reform, there are very large and strongly heterogeneous tax changes across taxpayers, with the percentage change in the net-of-tax rate varying between $-20 \%$ and $+42 \%$. These differences in tax treatments across groups are larger than the tax treatment differences created by the Tax Reform Act of 1986 in the U.S. and the Tax Reform of the Century in Sweden in 1991, two reforms that have been extensively analyzed in the literature. For the 1994-reform, tax changes are also very large and heterogeneous, but not quite to the same degree as for the 1987-reform.

Figures 4 and 5 show the variation in the taxation of negative and positive capital income around the same two reform episodes. The figures are constructed in the same way as Figure

\footnotetext{
${ }^{8}$ The population shares of the seven groups do not quite sum to $100 \%$ due to a small number of taxpayers below the excemption level for the bottom bracket.
} 
3 above. For the 1987-reform, the tax variation on capital income, especially negative capital income, is even stronger than for labor income. The marginal net-of-tax rate for those in the top bracket increased by more than 50\% (40\%) in the case of negative (positive) capital income, while other groups of taxpayers experienced much smaller increases or reductions in the net-oftax rate. The 1994-reform have much smaller effects than the 1987-reform and, importantly, the tax variation created by the 1994-reform is qualitatively very different. For positive capital income, for example, the net-of-tax rate is reduced at the top and increased at the bottom directly opposite the 1987-reform.

Although the tax changes around 1987 and 1994 constitute the strongest variation in the data, there is in fact a lot of variation throughout the period we consider (1984-2005). Importantly, the tax variation in other years is often qualitatively different in terms of who experience tax increases and who experiences tax cuts.

\subsection{Graphical Evidence}

Before reporting results from panel regression analysis in the next section, we present graphical evidence on taxable income responses using the large 1987-reform. Figure 6 shows the evolution of labor and capital income around the 1987-reform for treatment and control groups, which are defined based on the reform-induced tax variation shown in Figures 3-5. The top panel in Figure 6 considers the effect on labor income under two alternative treatment group definitions using the grouping in Figure 3: Treatment 1 includes all groups in Figure 3 who experience an increase in the marginal net-of-tax rate on labor income as a result of the reform (1986-1989 difference), while Treatment 2 includes the same groups except those in the middle bracket who experience a relatively small net-of-tax rate increase. These groups are compared to a control group including those groups in Figure 3 who experience a decrease in the marginal net-of-tax rate as a result of the reform. The bottom panel in Figure 6 considers the effect on positive capital income based on the grouping in Figure 5, with the treatment (control) group defined as those who experience an increase (decrease) in the marginal net-of-tax rate on positive capital income resulting from the reform. In both panels, the vertical line at 1986 denotes the last pre-reform year (as the reform was passed in parliament during 1986 and changed tax rates starting from 1987), and income levels in 1986 are normalized to 100 in both treatment and control groups. 
For both labor and capital income, Figure 6 shows that income trends are completely parallel in the years prior to the reform and then start to diverge precisely in 1987, the first year of tax cuts on the treatments and tax hikes on the controls. For labor income, the effect on taxable income is larger in absolute terms under Treatment 2 than under Treatment 1, consistent with the fact that Treatment 2 is based only on those experiencing the largest tax cuts. For both labor and capital income, most of the effect of the tax reform takes place within a period of 3 years. The figure also reports basic difference-in-differences estimates of the elasticity of taxable income (standard errors in parentheses), comparing treatment and control groups over the 3-year interval from 1986 to 1989 . The estimates $\mathrm{DD}_{1}$ and $\mathrm{DD}_{2}$ in the top panel refer to Treatment 1 and Treatment 2, respectively. DD estimates in both panels are based on 2SLS regressions of log income on an after-reform time dummy, a treatment-group dummy and the log marginal net-of-tax rate, the latter variable being instrumented by the interaction of the after-reform and treatment-group dummies. Elasticities of both labor and capital income lie in the range between 0.2 and 0.3. Interestingly, the estimated labor income response under Treatment 2 is larger than under Treatment 1 , not just in absolute terms, but also in elasticity terms. This suggests that larger tax changes may be associated with larger estimated elasticities, a point we come back to below.

Having considered simple graphical evidence for one specific reform episode, the next section turns to panel regressions that exploit all tax reform variation over time and make use of the rich socio-economic information in the data.

\section{Empirical Results from Panel Regressions}

In the following, we describe the results from 2SLS panel estimations using mechanical tax changes as instruments. We present separate estimations for labor income, negative capital income, and positive capital income. The first-stage regressions (not shown) are always very strong. For the second stage, we focus on the key elasticity parameters of interest and do not show point estimates associated with the large number of covariates that we control for. The exact details of the different regression specifications that we consider are provided in the notes of regression tables. In all regressions, standard errors are clustered by individual in order to account for any individual-specific correlation in income changes over time. 


\section{Labor Income Elasticities}

The first set of results is presented in Table 4, which shows estimates of labor income elasticities based on specifications that assume no income effects and no cross-tax effects. The potential importance of income effects and cross-tax effects are considered later on. The table splits the sample by wage earners (Panel A) and self-employed individuals (Panel B), and shows results for a number of different specifications and sample restrictions that have been discussed in the literature.

The different rows in the table consider different specifications of pre-reform income controls: no income controls, the different income controls proposed by Gruber and Saez (2002) and Kopczuk (2005), along with specifications that include richer controls for transitory income components by including log-income changes from period $s-2$ to $s-1$ and from $s-1$ to $s$. Results in the previous literature have been extremely sensitive to the specification of prereform income controls. The different columns in the table consider different sample restrictions (in addition to the basic restrictions described in section 3): all taxpayers with positive broad income (defined as the sum of labor income, other personal income and capital income) in columns (1) and (5), taxpayers with broad income above DKK 50,000 (about USD 10,000) in columns (2) and (6), and taxpayers with broad income above DKK 100,000 (about USD 20,000) in columns (3) and (7). Results in the previous literature have been very sensitive to such income restrictions due to mean reversion at the bottom. Finally, columns (4) and (8) consider results when taxpayers located close to kink points are excluded. This is done because the GruberSaez style specifications we consider assume that taxpayers behave as if they are located in the interior of brackets and do not bunch at kink points. If there is significant bunching at kink points, this may create bias in the estimates. As shown by Chetty et al. (2011) and Kleven et al. (2010), there is indeed bunching at the top kink in Denmark (but not at the bottom and middle kinks) and we therefore investigate if our results are sensitive to this.

The table shows that results are extremely robust to both the specification of pre-reform income controls and sample selection. While it does matter whether any income controls are included (first row versus subsequent rows), the exact specification of pre-reform income controls is not important. Moreover, excluding taxpayers at the bottom (to avoid mean reversion at the bottom) and excluding taxpayers around kink points (to avoid results being attenuated by 
bunching) have very little impact on the results. ${ }^{9}$ Across all the specifications shown in the table (ignoring the first row without any income controls), the elasticity of labor income vary between 0.04 and 0.06 for wage earners and between 0.08 and 0.10 for self-employed individuals.

In the following tables, we no longer show the different sample restrictions considered in Table 4, because those sample restrictions do not matter for any of our results. In all the tables below, we include all taxpayers with positive broad income and do not drop observations around kink points (as in columns (1) and (5) of Table 4). Table 5 consider the importance of income effects by including virtual income in the specification, and again we split the sample by wage earners and self-employed individuals. As a benchmark, columns (1) and (4) repeat results from a specification without income effect as in Table 4. Those columns are labelled "compensated elasticity", although in a specification without income effects there is of course no distinction between the compensated and uncompensated elasticity. Columns (2)-(3) and (5)-(6) show the uncompensated elasticity and income elasticity based on specifications with income effects. In those specifications, the compensated elasticity is approximately equal to the uncompensated elasticity minus the income elasticity. ${ }^{10}$

The general finding in Table 5 is that income elasticities are negative, implying that leisure is a normal good, but very small. The finding of small income effects is consonant with the public finance and labor economics literatures in general. While the point estimates of income effects are roughly the same for wage earners and the self-employed, the income effects are statistically significant only for wage earners where we have many more observations than for the self-employed. In all specifications, the compensated elasticity implied by the specification with income effects correspond closely to the elasticity obtained from the specification without income effects. Importantly, the results in Table 5 are again extremely robust to the specification of pre-reform income controls.

\footnotetext{
${ }^{9}$ It is not very surprising that bunching around kink points has no significant effect on our results. Although there is clear bunching at the top kink in Denmark, it affects a small part of the population (see Table 3) and is small in magnitude, especially for wage earners where the elasticity implied by bunching is only 0.01 (Chetty et al. 2011). Bunching is stronger for self-employed individuals, which is consistent with our finding that the impact of excluding taxpayers around kink points is slightly larger for the self-employed than for wage earners. Notice also that, as one would expect, elasticities become larger when excluding observations close to kinks, because those taxpayers are constrained in their response to the reform-driven tax variation that we use for identification.

${ }^{10}$ This is an approximation because the income elasticity should be weighted by labor income as a share of total income. Since this share is close to one for most taxpayers, this weighting have no large impact on the calculation of the compensated elasticity.
} 


\section{Capital Income Elasticities}

We now turn to the analysis of capital income responses. Capital income is a net income concept that may be either positive or negative, and is in fact negative for the vast majority of taxpayers in Denmark due to interest payments on mortgages and other loans. As described in section 2 , the tax treatment of capital income is very different depending on whether the net value is positive or negative, with much higher tax rates on positive than on negative capital income. Since we consider log-linear regression specifications that do not allow for non-positive income values, we consider capital income in absolute value and run separate regressions for negative and positive capital income. ${ }^{11}$

The results are shown in Table 6, which compares elasticities for negative and positive capital income in columns (2) and (3) to elasticities for labor income in column (1). The table shows results for all taxpayers (wage earners and self-employed individuals together) and is based on specification without income effects. Notice that we would expect the elasticity of negative capital income (in absolute value) to be negative and the elasticity of positive capital income to be positive, and this is indeed what we find for all specifications. Overall, capital income elasticities tend to be 2-3 times larger in absolute value than labor income elasticities, and again the results are very robust the specification of pre-reform income controls. Elasticities of negative capital income vary between -0.07 and -0.13 across all specifications, while elasticities of positive capital income vary between 0.08 and 0.14 .

\section{Responses to Small vs. Large Tax Reforms}

In general, the responses estimated above are fairly modest, consistent with many other micro studies of intensive responses to taxation such as hours-of-work responses (e.g. Heckman 1993; Blundell and MaCurdy 1999; Meghir and Phillips 2010; Chetty 2011). An important question is

\footnotetext{
${ }^{11}$ This strategy requires us to drop individuals with zero capital income as well as those whose capital income switch sign between base and post year. An additional argument for dropping observations around zero capital income is that the imposition of much higher marginal tax rates on positive than on negative capital income (after the 1987-reform) creates a large kink in the capital income tax schedule at zero. This is associated with strong incentives for bunching at zero capital income, a type of response that is not captured by the Gruber-Saez estimation strategy and may create bias as discussed earlier. Indeed, we find strong bunching in the data around zero capital income. While this is interesting by itself and might offer a different way of uncovering capital income elasticities, a key problem of exploiting bunching at zero capital income is that it is likely to partly reflect non-tax factors. Even without the tax kink, there would have been some excess clustering at zero as many taxpayers have not accumulated any saving or debt because of their stage in the life cycle (e.g. young taxpayers) or because of credit constraints.
} 
whether micro elasticities are small because they are attenuated by optimization frictions (such as inattention and adjustment costs) or because the "true" structural elasticity that overcomes optimization frictions and matters for long-run behavior is small. As argued by Chetty et al. (2011) and Chetty (2011), the estimation of long-run structural elasticities requires tax variation that is large enough to overcome frictions. The Danish setting allows us to explore this question, because the time period we consider includes one very large tax reform episode along with many smaller tax reform episodes. In particular, the 1987-reform was associated with extremely large tax variation (as shown in section 4) and this reform is perhaps the most widely discussed and salient tax reform in Danish history. To test the hypothesis that elasticities are larger when estimated from large tax changes as they overcome frictions and reveal the long-run structural elasticity, we compare responses to the 1987-reform with responses to all the subsequent smaller changes.

The results are shown in Table 7 for all reforms (1984-2005 period), 1987-reform (19841990 period), and post-1987 reforms (1991-2005 period) for labor income (Panel A) and positive capital income (Panel B). The elasticity estimations include all taxpayers (wage earners and selfemployed individuals together) and are based on specifications without income effects. We do not show results for negative capital income, because it is associated with very little identifying variation after the 1987-reform as there was just one bracket for negative capital income through most of this period (see Figure 2, Panel B). The lack of variation for negative capital income after the 1987-reform makes it difficult to separately estimate responses for this period and income type in a robust way.

The results in the table lend clear support to the hypothesis that micro elasticities are larger when estimated using large tax variation. The labor income elasticity estimated from the 1987reform is about $0.11-0.12$, which is $2-3$ times larger than elasticities based on the whole period and 3-6 times larger than elasticities based on the post-1987 reforms alone. These results are again robust to pre-reform income controls. Results for capital income are qualitatively similar, but the difference between large-reform elasticities (0.14-0.15) and small-reform elasticities (0.080.10 ) is not as strong as for labor income. It is intuitive that the size of the tax change matters more for labor income than for capital income, because labor income responses are likely to be affected by real adjustment costs (e.g. search costs) to a larger extent than capital income responses. On the other hand, frictions due to for example inattention would matter for both 
labor and capital income.

It is possible to learn more about the difference between small and large tax changes by zooming in on those parts of the 1987-reform that were associated with the largest tax changes. We may focus on specific groups that were most strongly affected by the reform and specific years that were associated with the very largest changes. This is essentially what we did in the graphical difference-in-differences analysis in section 4 , which did indeed give rise to larger elasticities than the large-reform elasticities in Table 7. Similarly, when we carry out panel estimations like those in Table 7 for those groups and years that were most strongly affected by the 1987-reform, the estimated elasticities become even larger than those for the 1987-reform in the table.

Our results are qualitatively consistent with the findings of Chetty et al. (2011), who compare bunching around small and large kinks in the Danish tax code to evaluate the importance of frictions in attenuating short-run responses and to estimate the long-run elasticity that overcomes frictions. But the magnitude of the elasticity that we find using the large 1987-reform is much larger than the elasticity found by Chetty et al. (2011) using bunching at the large top-tax kink. A likely explanation is that bunching around kink points, even large kink points, are much more affected by frictions due to the fact that bunching requires precise knowledge of bracket thresholds along with a very precise behavioral response, both of which may be costly to achieve due to adjustment costs, attention costs, etc. The reform-driven variation we consider is likely to be less affected by such aspects.

\section{Cross-Tax Effects Between Labor and Capital Income:}

The specifications so far have ignored potential cross-tax effects between labor and capital income. Table 8 considers such effects by presenting results from labor income regressions that include the marginal net-of-tax rates on both labor income and capital income. The specification does not include income effects on labor income, which are in any case weak and have little impact on the results. The table considers all taxpayers (Panel A), wage earners (Panel B), and self-employed individuals (Panel C). Each panel shows the own-tax elasticity on the left and the cross-tax elasticity on the right. As in all other tables, we consider a number of different specifications of pre-reform income controls.

Overall, the table suggests that cross-tax effects are not very important in the Danish tax 
system. Cross-tax elasticities are in general very small (and sometimes insignificant), and allowing for such cross-tax effects have very little impact on the own-tax elasticity compared to the earlier tables that ignores those effects. For wage earners, the cross-tax elasticity is positive and very small, suggesting weak complementarity between labor and capital for those individuals. For the self-employed, the cross-tax elasticity is negative and somewhat larger in absolute value (but not precisely estimated), suggesting weak substitutability between labor and capital income for those individuals. The finding that labor and capital income are substitutes for the self-employed is consistent with income shifting in response to differential tax treatment of the two income forms. While income shifting has been much discussed in the public finance literature (e.g. Slemrod 1995, 1998; Saez, Slemrod, and Giertz 2010), there exists relatively little direct evidence on this type of behavioral response. ${ }^{12}$

\section{Conclusion}

This paper presents an empirical study of taxable income responses using a series of tax reforms that provide substantial tax variation across individuals, income forms, and over time. The variation provided by the Danish tax reforms does not feature the same strong correlation between tax changes and income levels as the tax reforms in the U.S. (and other countries) that have been extensively studied in the past two decades. Arguably, this allows us to overcome the identification problems arising from non-tax changes in the income distribution and meanreversion that plague much of the existing literature (as discussed by e.g. Saez, Slemrod, and Giertz 2010). Unlike previous studies, our results are very robust to the specification of controls for non-tax changes in the income distribution and mean reversion, which suggests that we have controlled in a sufficiently rich way for non-tax factors impacting on taxable income. The Danish setting therefore offers a useful laboratory for a credible estimation of taxable income responses.

As pointed out by Slemrod (1998) and Slemrod and Kopczuk (2002), taxable income elasticities are not structural parameters that depend only on individual preferences. They depend in important ways on the opportunities for tax avoidance and tax evasion, which in turn depend on the tax structure (especially the broadness of tax bases) and on tax enforcement. The fairly low

\footnotetext{
${ }^{12}$ Previous evidence on income shifting include Pirttilä and Selin (2011) on shifting between labor and capital income in Finland, Slemrod (1996) and Gordon and Slemrod (2000) on shifting between personal and corporate income in the United States, and Kleven and Waseem (2011) on shifing between wage income and self-employment income in Pakistan.
} 
taxable income elasticities that we find for Denmark, despite the presence of very high marginal tax rates, suggests that the Danish system offers small opportunities for avoidance and evasion. There are two main reasons for this. First, tax bases are very broad and offer limited opportunities for deductions and negative capital income to count against the income tax base. Second, as shown by Kleven et al. (2011), tax enforcement is very effective and overall tax compliance is high due to the widespread use of double-reporting by third parties such as employers and financial institutions. The overall conclusion that emerges from the two studies together is that a tax system with the broadest possible bases and extensive use of information reporting can impose high marginal tax rates with fairly modest behavioral responses. 


\section{References}

Aarbu, K. and T. Thoresen (2001). "Income Responses to Tax Changes - Evidence from the Norwegian Tax Reform." National Tax Journal 54, 319-334.

Atkinson, A., T. Piketty and E. Saez (2011). "Top Incomes in the Long Run of History." Journal of Economic Literature 49, 3-71.

Auten, G. and R. Carroll (1999). "The Effect of Income Taxes on Household Behavior." Review of Economics and Statistics 81, 681-693.

Blomquist, S. and H. Selin (2010). "Hourly Wage Rate and Taxable Labor Responsiveness to Changes in Marginal Tax Rates." Journal of Public Economics 94, 978-989.

Blundell, R. W. and T. MaCurdy (1999). "Labor Supply: A Review of Alternative Approaches," in O. Ashenfelter and D. Card (eds.), Handbook of Labor Economics vol. 3A, Elsevier, Amsterdam.

Brewer, M., E. Saez, and A. Shephard (2010). "Means Testing and Tax Rates on Earnings," chapter 2 in Dimensions of Tax Design: the Mirrlees Review, Oxford University Press, Oxford.

Chetty, R. (2011). "Bounds on Elasticities with Optimization Frictions: A Synthesis of Micro and Macro Evidence on Labor Supply." NBER Working Paper 15616, February 2011.

Chetty, R., J. Friedman, T. Olsen, and L. Pistaferri (2011). "Adjustment Costs, Firm Responses, and Micro vs. Macro Labor Supply Elasticities: Evidence from Danish Tax Records." Forthcoming Quarterly Journal of Economics.

Gordon, R. and J. Slemrod (2000). "Are 'Real' Responses to Taxes Simply Income Shifting Between Corporate and Personal Tax Bases?" In J. Slemrod (ed.), Does Atlas Shrug? The Economic Consequences of Taxing the Rich, Russell Sage Foundation and Harvard University Press, New York.

Feldstein, M. (1995). "The Effect of Marginal Tax Rates on Taxable Income: A Panel Study of the 1986 Tax Reform Act." Journal of Political Economy 103, 551-572.

Feldstein, M. (1999). "Tax Avoidance and the Deadweight Loss of the Income Tax." Review of Economics and Statistics 81, 674-680.

Gelber, A. (2010). "Taxation and the Earnings of Husbands and Wives." Working paper, University of Pennsylvania.

Giertz, S. (2007). "The Elasticity of Taxable Income over the 1980s and 1990s." National Tax 
Journal 60, 743-768.

Goolsbee, A. (2000). "What Happens When You Tax the Rich? Evidence from Executive Compensation." Journal of Political Economy 108, 352-378.

Gruber, J. and E. Saez (2002). "The Elasticity of Taxable Income: Evidence and Implications." Journal of Public Economics 84, 1-32.

Hansson, Å. (2007). "Taxpayers' Responsiveness to Tax Rate Changes and Implications for the Cost of Taxation in Sweden." International Tax and Public Finance 14, 563-582.

Heckman, J. (1993). "What Has Been Learned About Labor Supply in the Past Twenty Years?" American Economic Review Papers and Proceedings 83, 116-121.

Kleven, H. J., M. Knudsen, C. T. Kreiner, S. Pedersen, and E. Saez (2011). "Unwilling or Unable to Cheat? Evidence from a Tax Audit Experiment in Denmark." Econometrica 79, 651-692.

Kleven, H. J. and M. Waseem (2011)."Tax Notches in Pakistan: Tax Evasion, Real Responses, and Income Shifting." LSE Working Paper, May 2011.

Kopczuk, W. (2005). "Tax Bases, Tax Rates, and the Elasticity of Reported Income." Journal of Public Economics 89, 2093-2119.

Meghir, C. and D. Phillips (2010). "Labour Supply and Taxes," chapter 3 in Dimensions of Tax Design: the Mirrlees Review, Oxford University Press, Oxford.

Moffitt, R. and M. Wilhelm (2000). "Taxation and the Labor Supply Decisions of the Affluent," in J. Slemrod (ed.), Does Atlas Shrug? The Economic Consequences of Taxing the Rich, Harvard University Press and the Russel Sage Foundation, New York, NY.

Pirttilä, J. and H. Selin (2011). "Income Shifting within a Dual Income Tax System: Evidence from the Finnish Tax Reform of 1993." Scandinavian Journal of Economics 113, 120-144. Roine, J. and D. Waldenström (2008). "The evolution of top incomes in an egalitarian society: Sweden, 1903-2004." Journal of Public Economics 92, 366-387.

Saez, E. (2004). "Reported Incomes and Marginal Tax Rates, 1960-2000: Evidence and Policy Implications," in J. Poterba (ed.), Tax Policy and the Economy, vol. 18. MIT Press, Cambridge, MA.

Saez, E. (2010). "Do Taxpayers Bunch at Kink Points?" American Economic Journal: Economic Policy 2, 180-212.

Saez, E., J. Slemrod, and S. Giertz (2010). "The Elasticity of Taxable Income with Respect 
to Marginal Tax Rates: A Critical Review." Forthcoming Journal of Economic Literature.

Saez, E. and M. Veall (2005). "The Evolution of High Incomes in Northern America: Lessons from Canadian Evidence." American Economic Review 95, 831-849.

Sillamaa, M. A. and M. Veall (2001). "The Effect of Marginal Tax Rates on Taxable Income: a Panel Study of the 1988 Tax Flattening in Canada." Journal of Public Economics 80, 341-356. Slemrod, J. (1995). "Income Creation or Income Shifting? Behavioral Responses to the Tax Reform Act of 1986." American Economic Review Papers and Proceedings 85, 175-180.

Slemrod, J. (1996). "High Income Families and the Tax Changes of the 1980s: The Anatomy of Behavioral Response." In M. Feldstein and J. Poterba (eds.), Empirical Foundations of Household Taxation, University of Chicago Press, Chicago.

Slemrod, J. (1998). "Methodological Issues in Measuring and Interpreting Taxable Income Elasticities." National Tax Journal 51, 773-88.

Slemrod, J. and W. Kopczuk (2002). "The Optimal Elasticity of Taxable Income." Journal of Public Economics 84, 91-112. 


\section{Figure 1. The Evolution of Top Income Shares in Denmark}

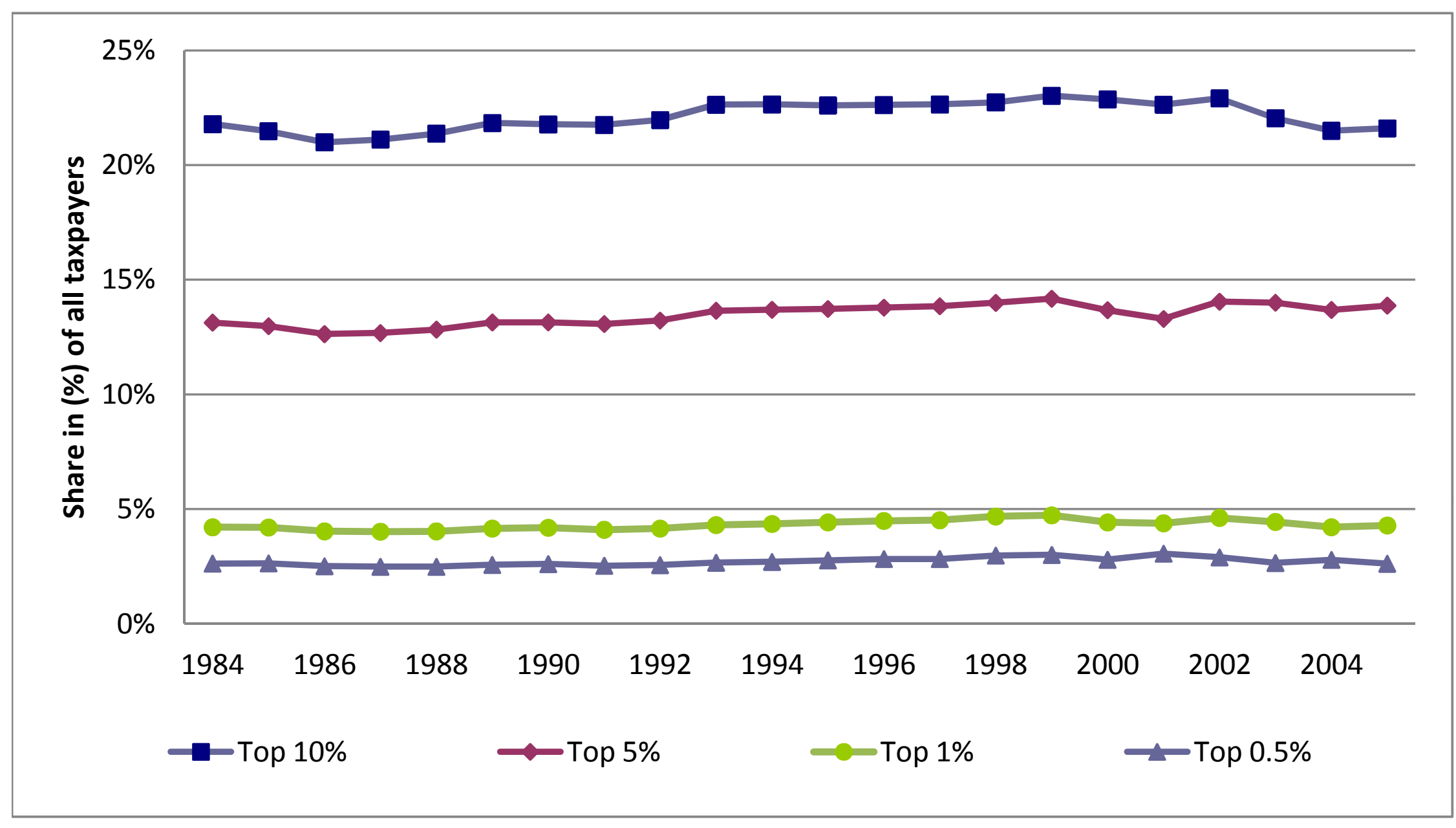

Notes: The income shares are based on income tax return information and consider a broad income measure that includes labor income, other personal income and capital income (see Table 1 for details about these income components). The sample includes all personal income tax filers aged 25 to 55. 


\section{Figure 2. Two Decades of Danish Tax Reform}

Panel A. Marginal Tax Rate on Labor Income

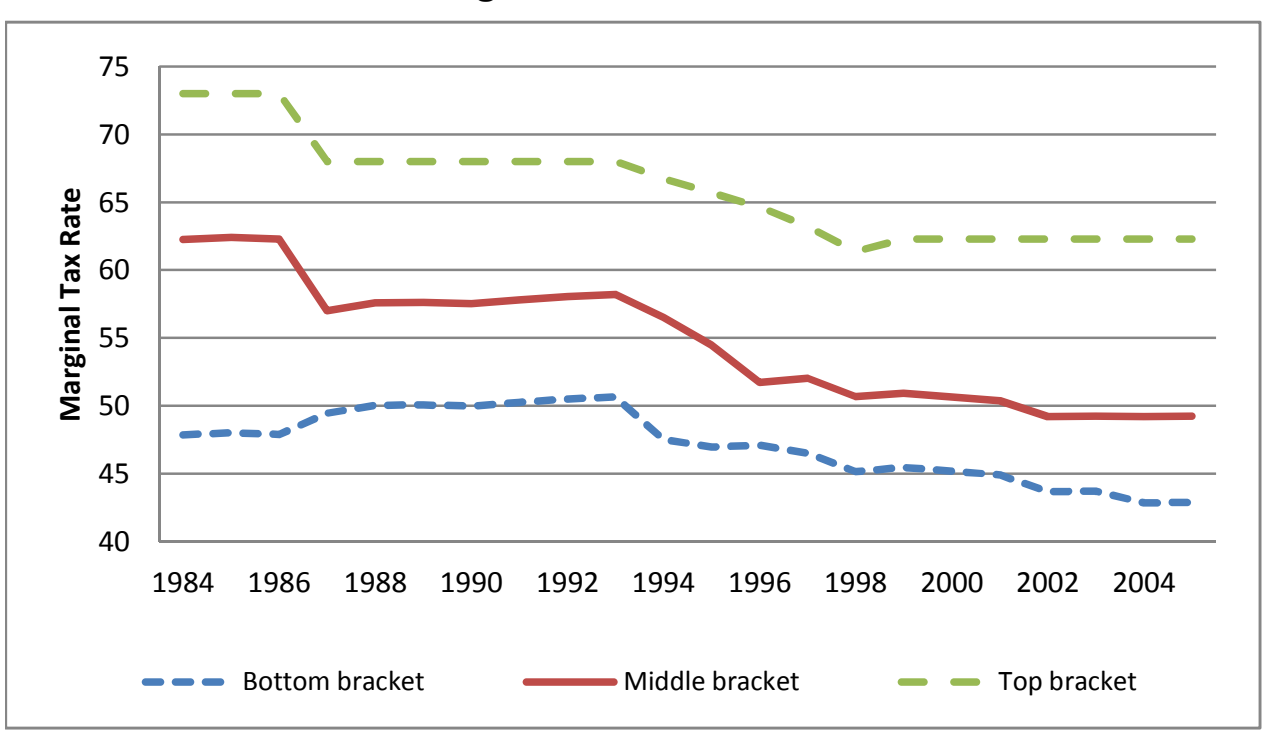

Panel C. Marginal Tax Rate on Positive Capital Income

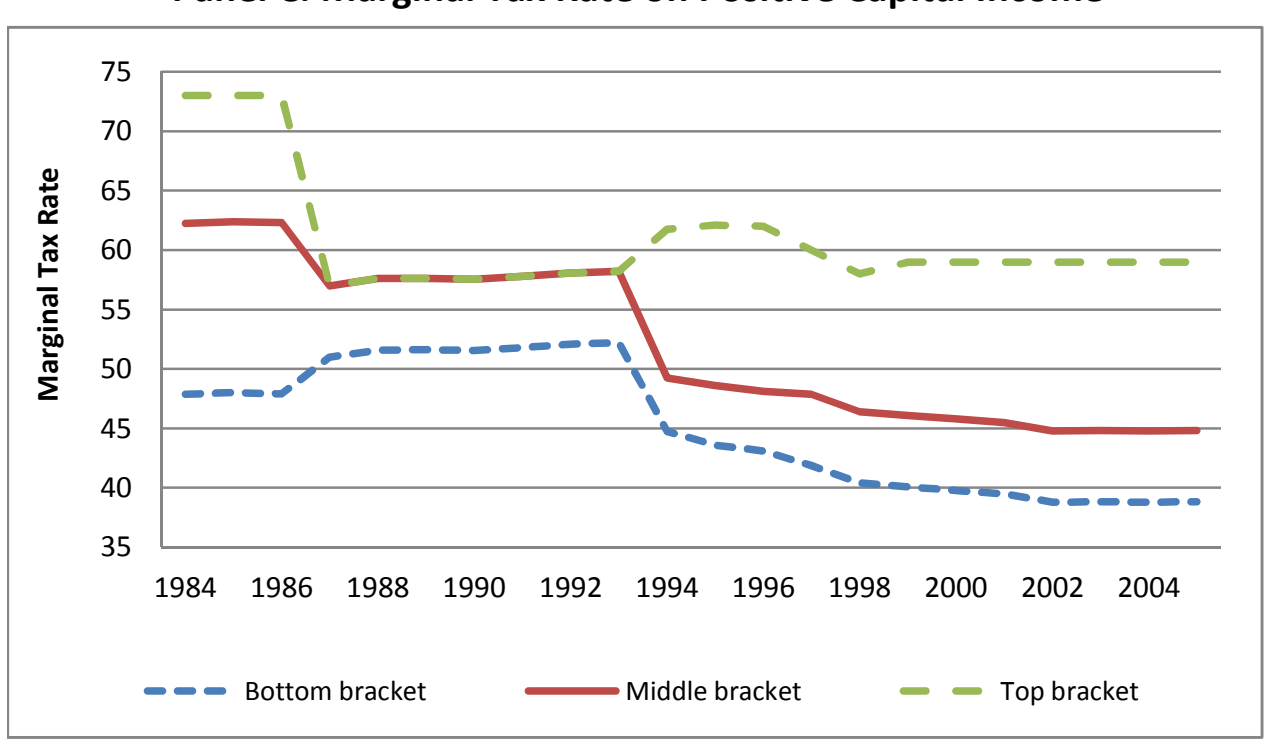

Panel B. Marginal Tax Rate on Negative Capital Income

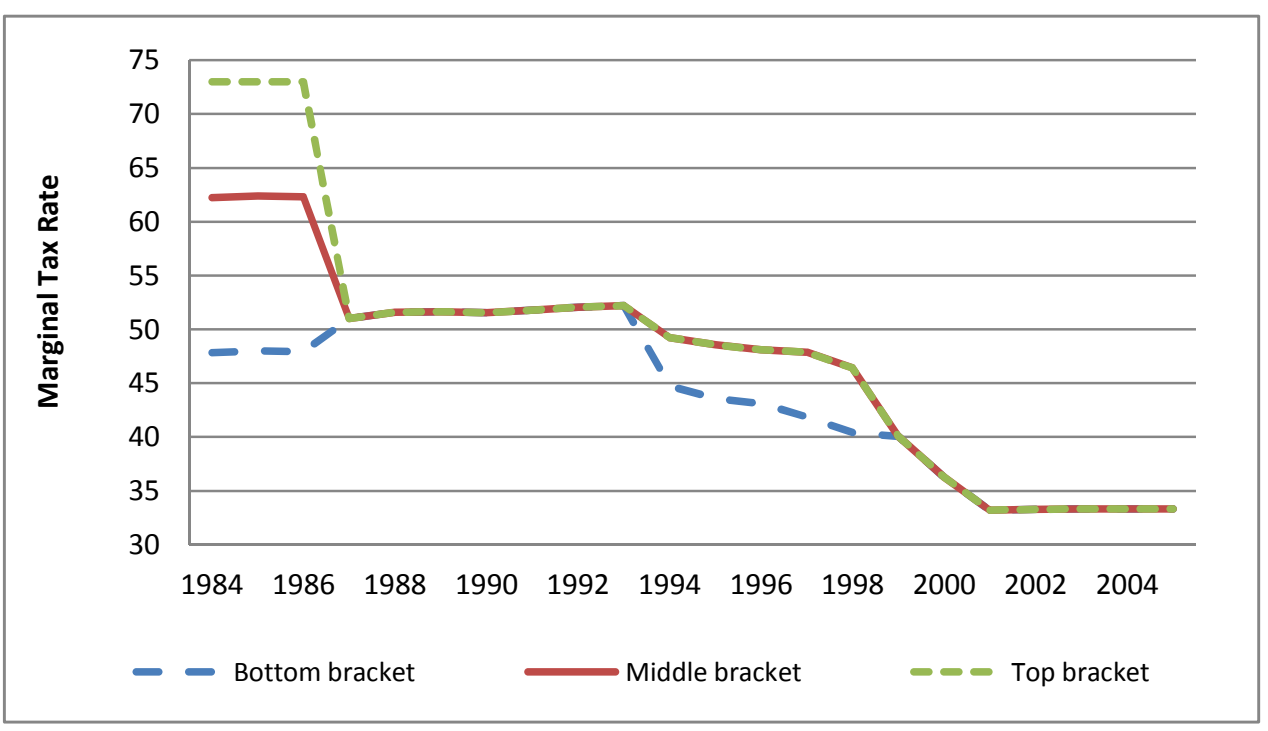

Panel D. Share of Taxpayers in the Three Tax Brackets

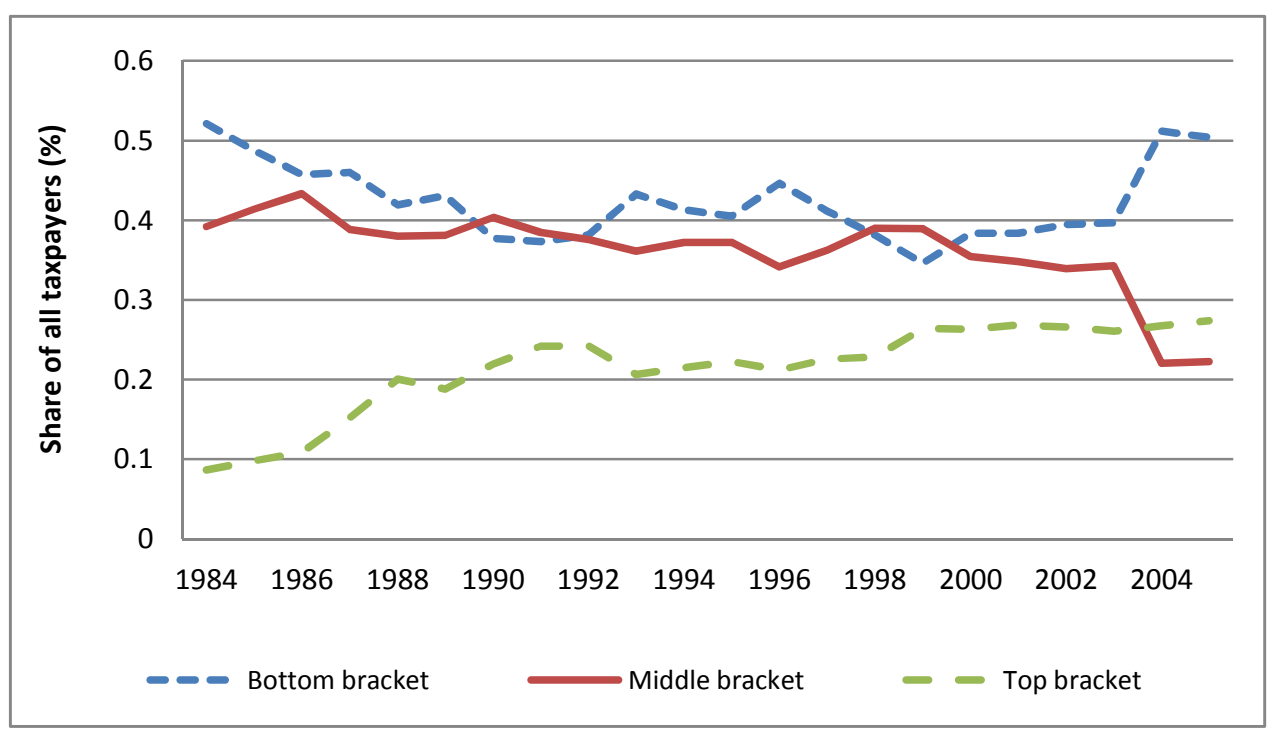


Figure 3. Mechanical Variation in the Marginal Net-of-Tax Rate on Labor Income

Panel A. 1987-Reform (1986-1989 Difference)

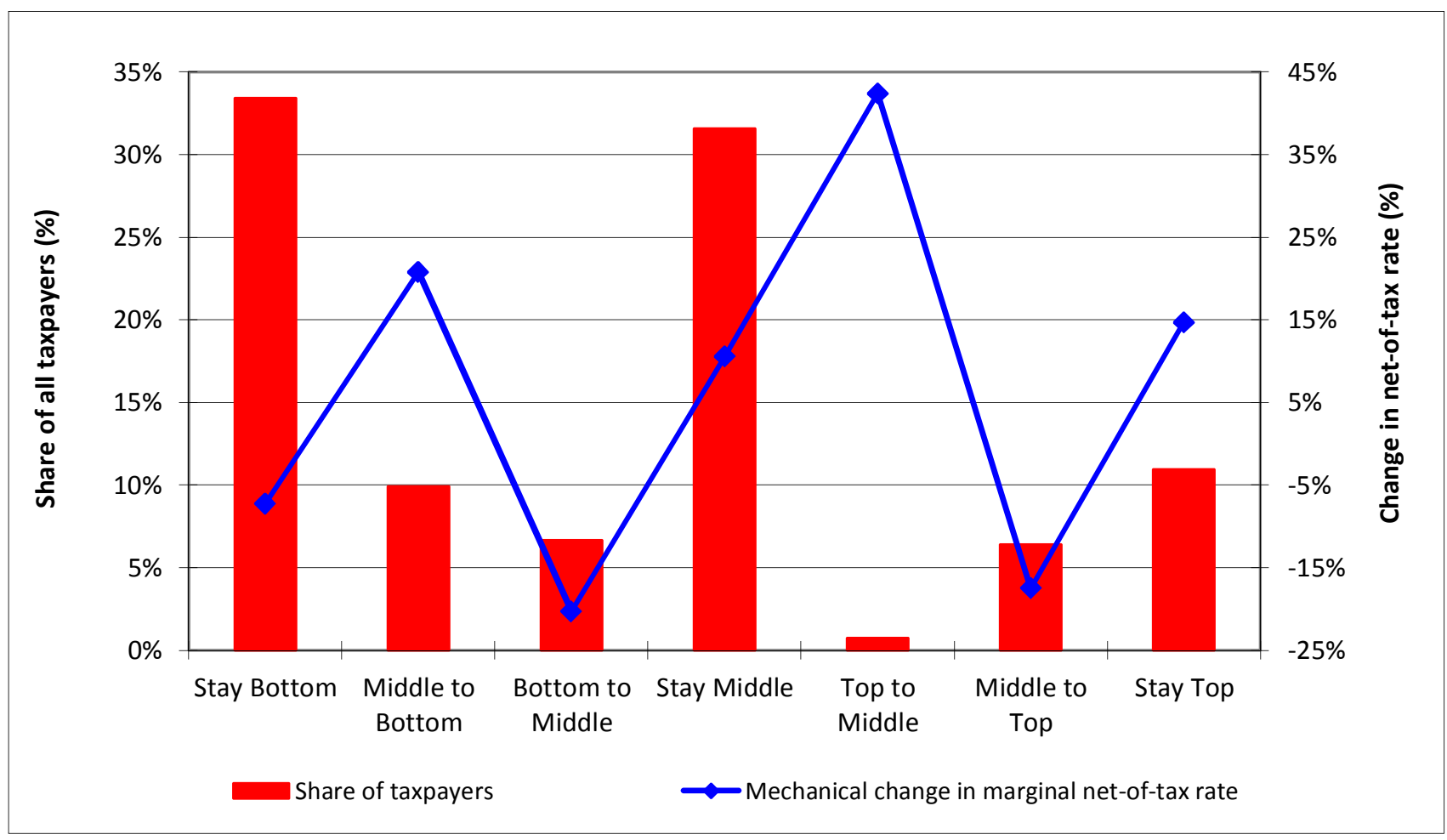

Panel B. 1994-Reform (1993-1996 Difference)

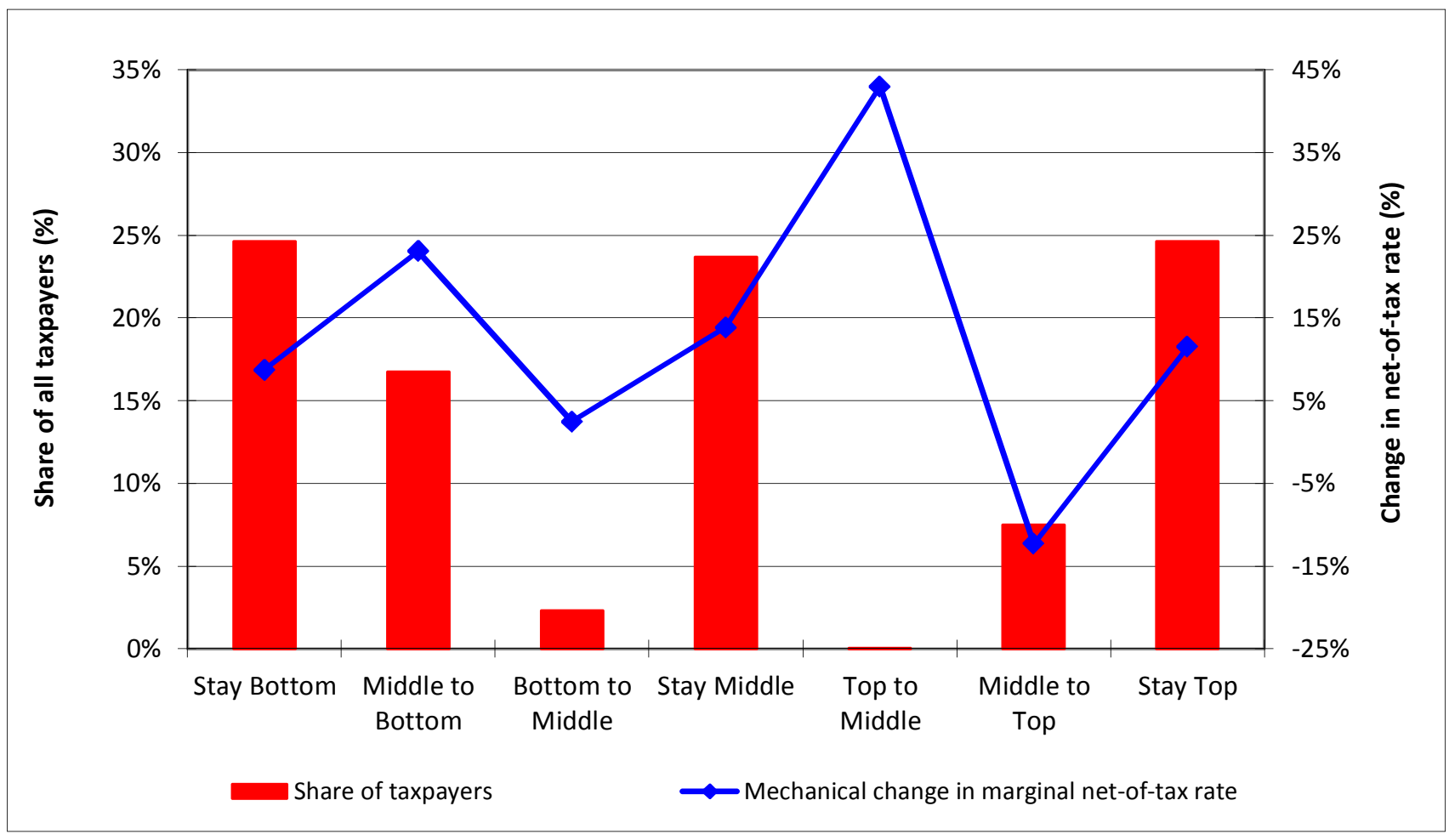


Figure 4. Mechanical Variation in the Marginal Net-of-Tax Rate on Negative Capital Income

Panel A. 1987-Reform (1986-1989 Difference)

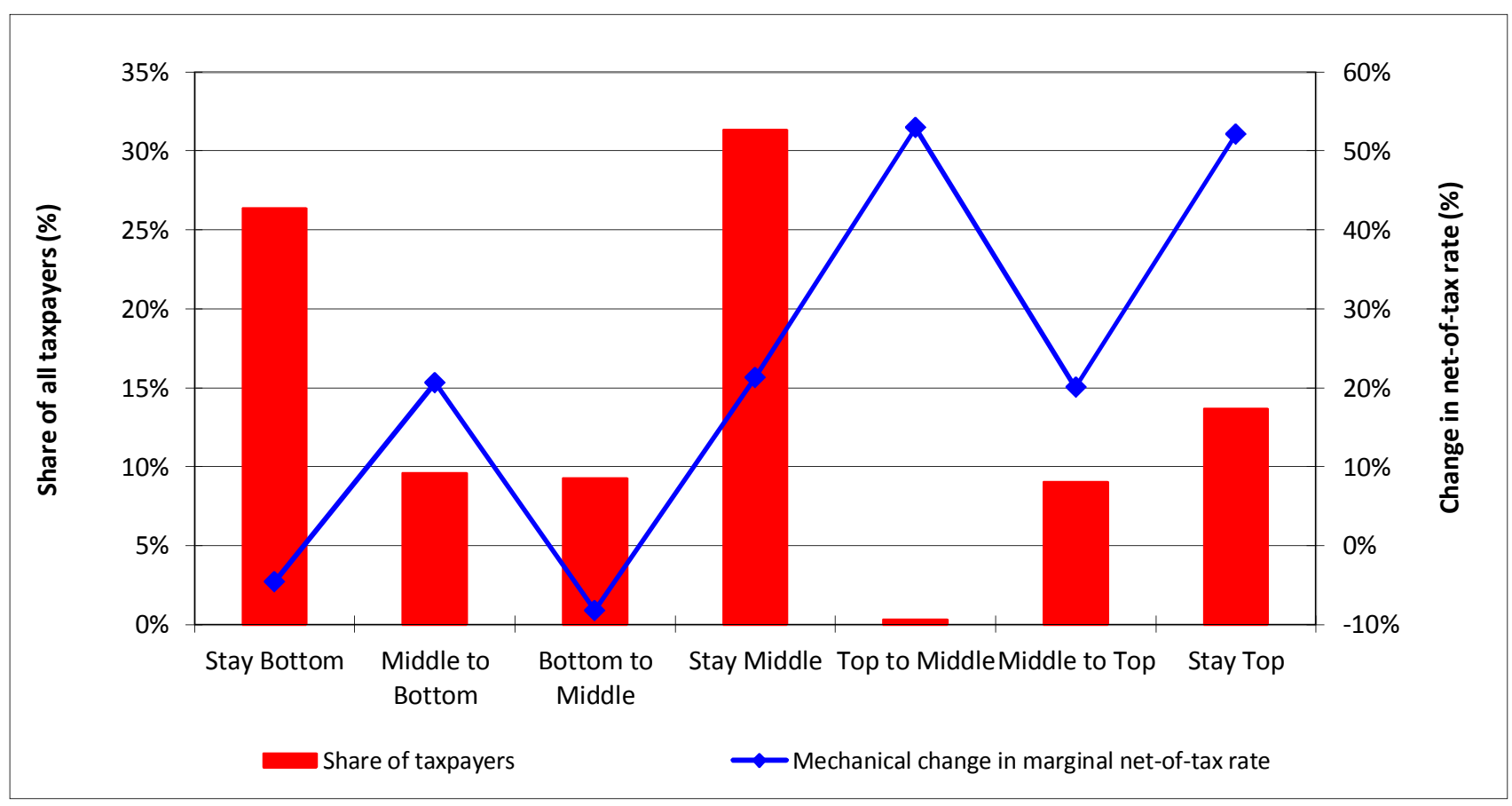

Panel B. 1994-Reform (1993-1996 Difference)

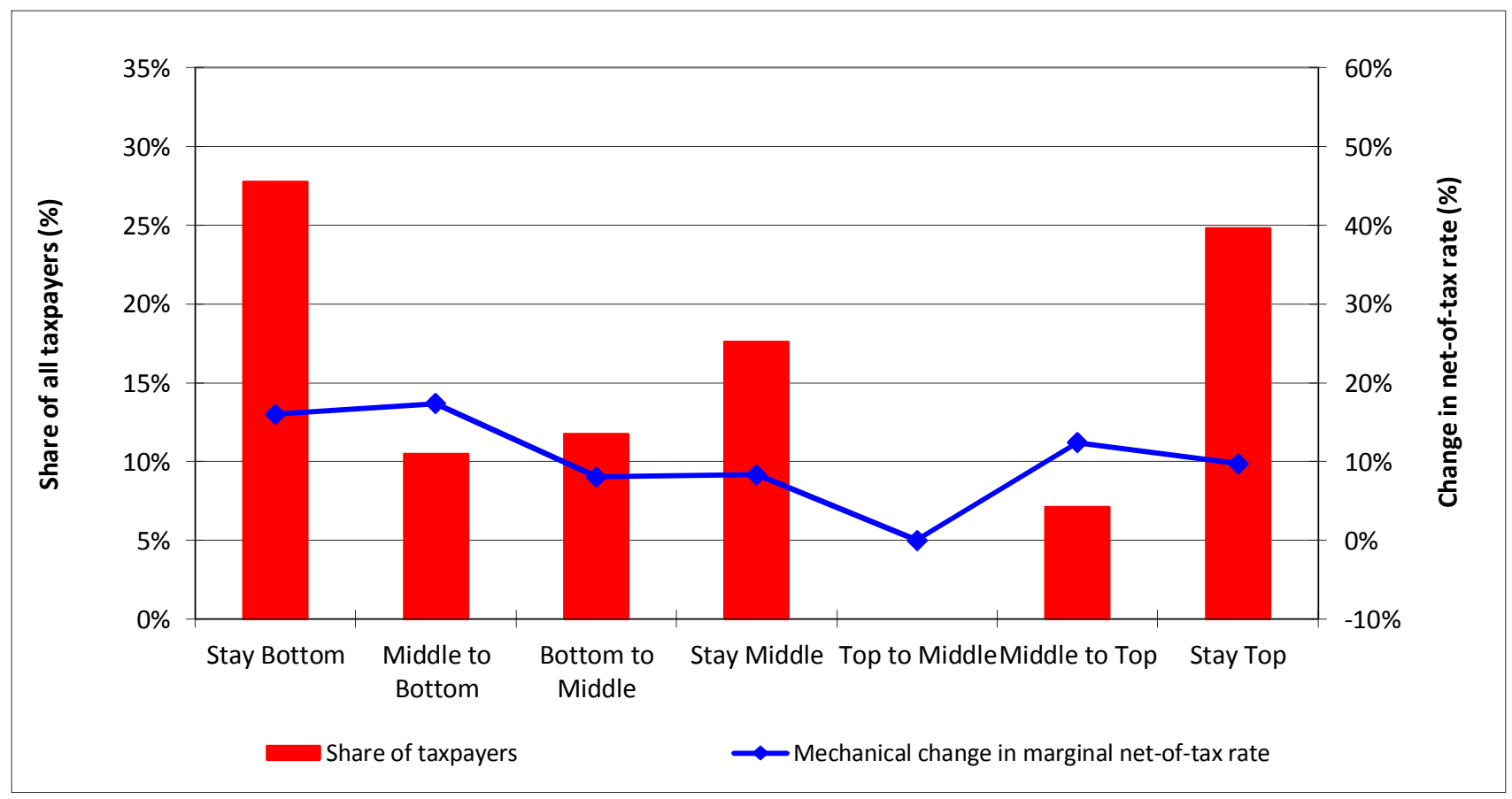


Figure 5. Mechanical Variation in the Marginal Net-of-Tax Rate on Positive Capital Income

Panel A. 1987-Reform (1986-1989 Difference)

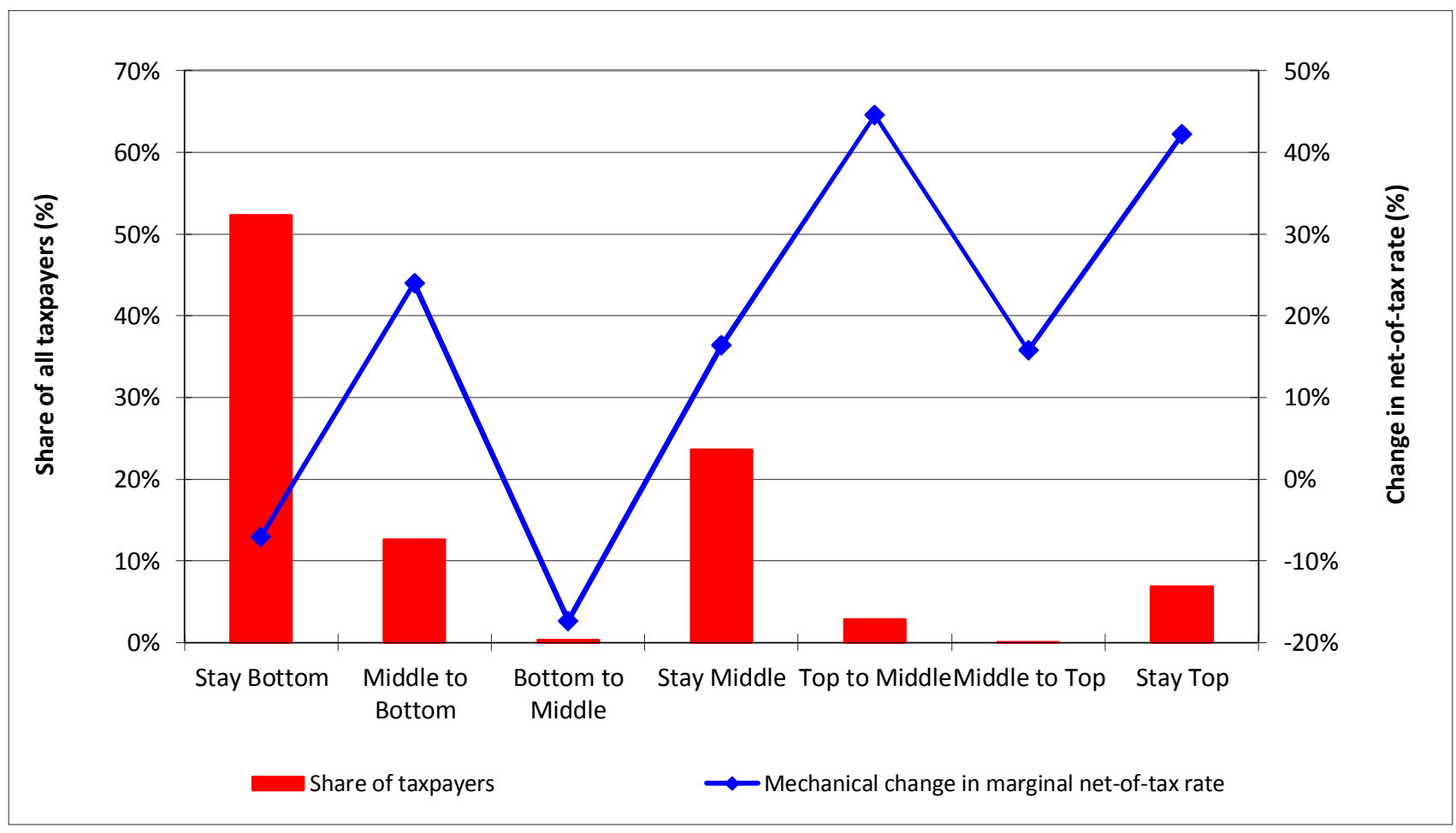

Panel B. 1994-Reform (1993-1996 Difference)

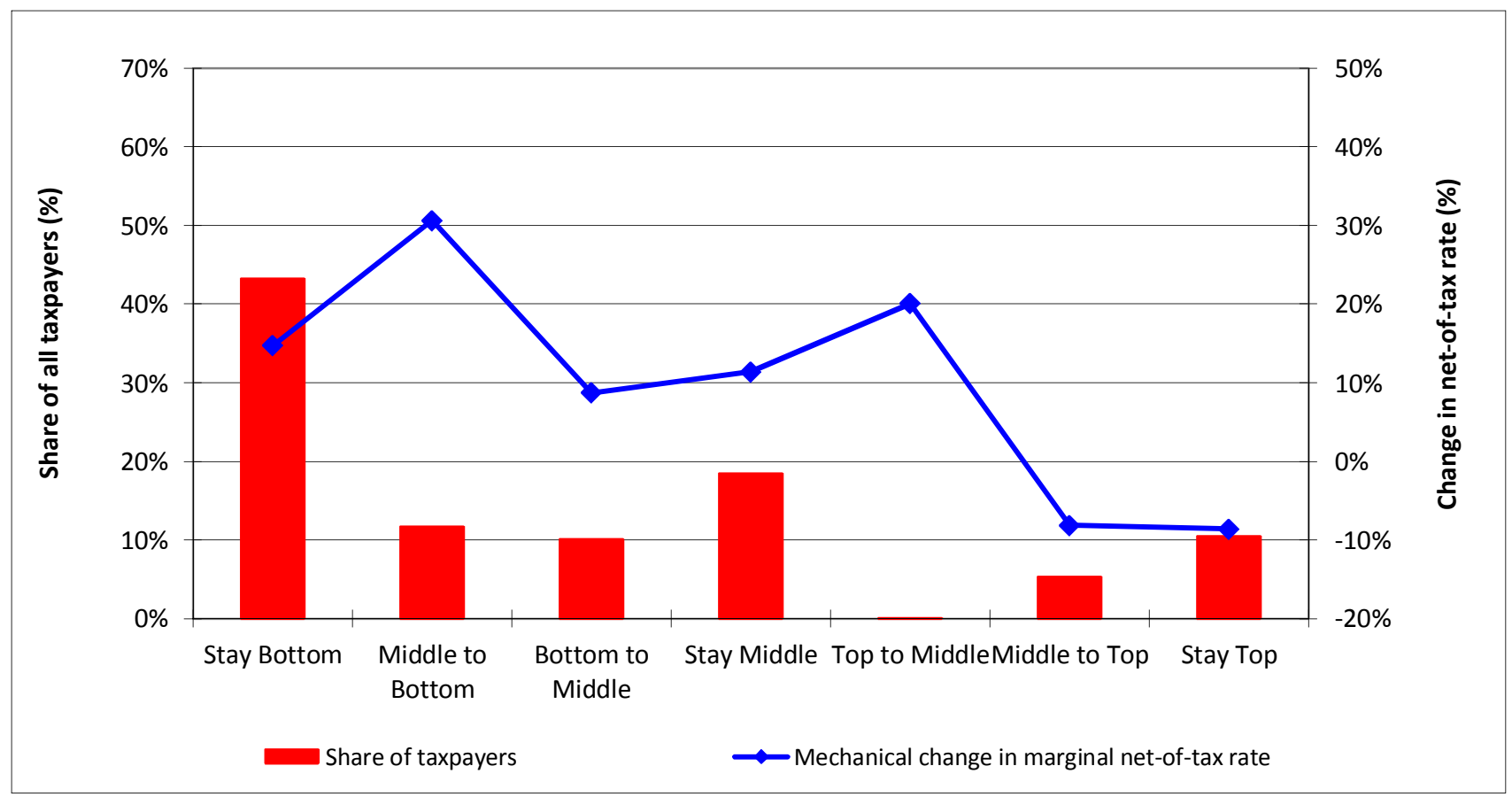


Figure 6. Graphical Evidence on Taxable Income Responses to the Danish 1987-Reform

\section{Panel A. Labor Income}

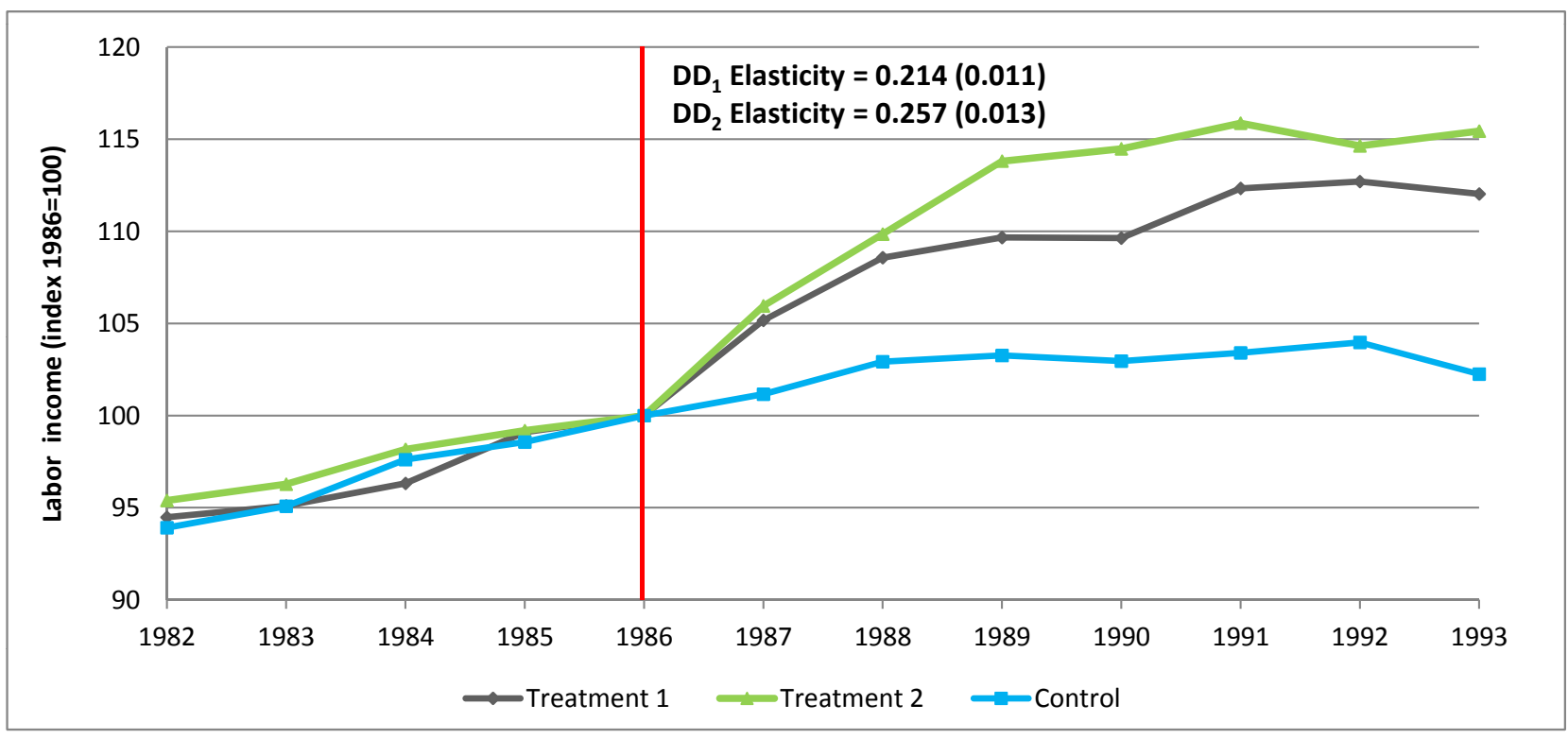

Panel B. Positive Capital Income

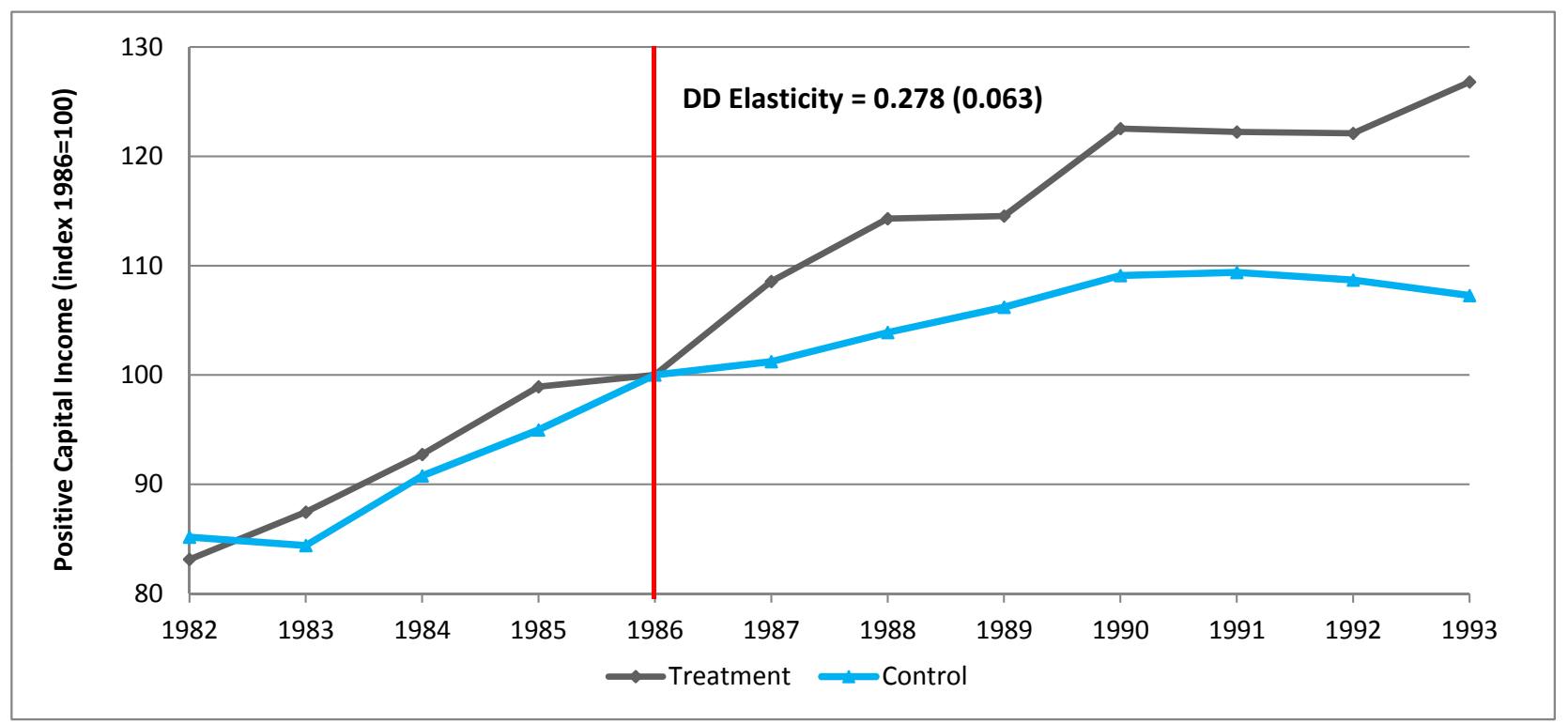

Notes: Panel A considers the effect on labor income under two treatment group definitions using the grouping in Figure 3 . Treatment 1 includes all groups in Figure 3 who experience an increase in the marginal net-of-tax rate on labor income as a result of the reform (1986-1989 difference), while treatment 2 includes the same groups except those in the middle bracket ("stay middle" group in Figure 3) who experience a relatively small net-of-tax rate increase. The control group includes those groups in Figure 3 who experience a decrease in the marginal net-of-tax rate as a result of the reform. Panel B considers the effect on positive capital income based on the grouping in Figure 5, with the treatment (control) group defined as those who experience an increase (decrease) in the marginal net-of-tax rate on positive capital income resulting from the reform. In both panels, only taxpayers who are in the sample in every year of the period under consideration (1984-1993) are included. The vertical line at 1986 denotes the last pre-reform year (as the reform was passed in parliament during 1986 and changed tax rates starting from 1987), and income levels in 1986 are normalized to 100 in both treatment and control groups (without loss of generality as identification come from percentage changes over time, not from absolute levels). Both panels show that income trends are completely parallel in the years prior to the reform and then start to diverge precisely in 1987, the first year of tax cuts on the treatment groups. Most of the effect of the tax reform takes place within a period of 3 years. The figure also reports basic difference-in-differences estimates of the elasticity of taxable income (standard errors in parentheses), comparing treatment and control groups over the 3-year interval from 1986 to 1989 . The estimates $\mathrm{DD}_{1}$ and $\mathrm{DD}_{2}$ in $\mathrm{Panel}_{\mathrm{A}}$ refer to treatment 1 and treatment 2, respectively. DD estimates in both panels are based on 2SLS regressions of log income on an after-reform time dummy, a treatmentgroup dummy and the log marginal net-of-tax rate, the latter variable being instrumented by the interaction of the after-reform and treatmentgroup dummies. 
Table 1. Income Concepts in the Danish Individual Income Tax

\begin{tabular}{|c|c|c|}
\hline Income concept & Acronym & Main items included \\
\hline 1. Labor Income & LI & Salary, wages, honoraria, fees, bonuses, fringe benefits, business earnings \\
\hline 2. Personal Income & PI & $\begin{array}{l}\text { LI + transfers, grants, awards, gifts, received alimony } \\
- \text { Labor Market Contribution, certain pension contributions }\end{array}$ \\
\hline 3. Capital Income & CI & $\begin{array}{l}\text { Interest income, rental income, business capital income } \\
\text { - interest on debt (mortgage, bank loans, credit cards, student loans) }\end{array}$ \\
\hline 4. Stock Income & SI & Dividends and realized capital gains from shares \\
\hline 5. Deductions & $\mathrm{D}$ & $\begin{array}{l}\text { Commuting, union fees, UI contributions, other work expenditures, } \\
\text { charity, paid alimony }\end{array}$ \\
\hline 6. Taxable Income ${ }^{1}$ & TI & $\mathrm{PI}+\mathrm{CI}+\mathrm{SI}-\mathrm{D}$ \\
\hline
\end{tabular}

1. The definition of taxable income in this table does not correspond to what is currently labelled "taxable income" in the Danish tax code, which excludes stock income as it is taxed on a separate schedule (see Table 2 below). 
Table 2. Tax Bases and Tax Rates over Time in the Danish Individual Income Tax System

\begin{tabular}{|c|c|c|c|c|c|c|c|c|}
\hline \multirow[b]{2}{*}{ Tax type $^{1}$} & \multicolumn{2}{|c|}{1986} & \multicolumn{2}{|c|}{1993} & \multicolumn{2}{|c|}{1998} & \multicolumn{2}{|c|}{2005} \\
\hline & Base & Rate (\%) & Base & Rate (\%) & Base & Rate (\%) & Base & Rate (\%) \\
\hline Regional tax ${ }^{2}$ & TI & 28.1 & $\mathrm{PI}+\mathrm{CI}-\mathrm{D}$ & 30.2 & $\mathrm{PI}+\mathrm{CI}-\mathrm{D}$ & 32.4 & $\mathrm{PI}+\mathrm{CI}-\mathrm{D}$ & 33.3 \\
\hline \multicolumn{9}{|l|}{ National taxes: } \\
\hline Bottom tax & $\mathrm{TI}$ & 14.4 & $\mathrm{PI}+\mathrm{CI}-\mathrm{D}$ & 22.0 & $\mathrm{PI}+\mathrm{CI}-\mathrm{D}$ & 8.0 & $\mathrm{PI}+[\mathrm{CI}>0]$ & 5.5 \\
\hline Middle tax & $\mathrm{TI}$ & 14.4 & $\mathrm{PI}+[\mathrm{CI}>0]$ & 6.0 & $\mathrm{PI}+\mathrm{CI}$ & 6.0 & $\mathrm{PI}+[\mathrm{CI}>0]$ & 6.0 \\
\hline Top tax & $\mathrm{TI}$ & 10.8 & PI & 12.0 & $\mathrm{PI}+[\mathrm{CI}>21 \mathrm{k}]$ & 15.0 & $\mathrm{PI}+[\mathrm{CI}>0]$ & 15.0 \\
\hline Social security contribution & $\mathrm{TI}$ & 5.5 & - & - & - & - & - & - \\
\hline Labor market contribution ${ }^{3}$ & - & - & - & - & LI & 8.0 & LI & 8.0 \\
\hline EITC & - & - & - & - & - & - & LI & 2.5 \\
\hline Tax on stock income ${ }^{4}$ & - & - & SI & $30.0 ; 40.0$ & SI & $25.0 ; 40.0$ & SI & $28.0 ; 43.0$ \\
\hline Marginal tax ceiling 5 & TI & 73.0 & $\mathrm{PI} / \mathrm{CI} / \mathrm{TI}$ & 68.0 & $\mathrm{PI} / \mathrm{CI} / \mathrm{TI}$ & 58.0 & $\mathrm{PI} / \mathrm{CI} / \mathrm{TI}$ & 59.0 \\
\hline
\end{tabular}

1. Tax rates are cumulative. For example, the marginal tax rate in the top bracket in 1986 is equal to $28.1+14.4+14.4+10.8+5.5=73.2 \%$ (but see footnote 4 regarding marginal tax ceiling adjustment)

2. The regional tax includes municipal, county, and church taxes. The regional tax rate in the table is an average across all municipalities in Denmark in each year.

3. After the introduction of the labor market contribution, labor income enters the other tax bases net of the labor market contribution. Hence, in those years, the effective tax rate on labor income equals the statutory tax rate times (1 - labor market contribution).

4. After the 1987-reform, the taxation of stock income is completely separate from the rest of the income tax and follows a two-bracket progressive schedule with the marginal tax rates shown in the table.

5. If the sum of all regional and national tax rates (excluding the stock income tax after the 1987-reform) exceeds the specified ceiling, the top tax is adjusted downwards until the the marginal tax rate equals the ceiling. 
Table 3. Summary Statistics for the Estimation Sample, 1984-2005

\begin{tabular}{|c|c|c|c|}
\hline & $\begin{array}{l}\text { Full Sample } \\
\text { (1) }\end{array}$ & $\begin{array}{c}\text { Wage Earners } \\
\text { (2) }\end{array}$ & $\begin{array}{c}\text { Self-Employed } \\
\text { (3) }\end{array}$ \\
\hline \multicolumn{4}{|l|}{ Demographics: } \\
\hline Age & 40.5 & 40.0 & 48.3 \\
\hline Number of children (0-17 years) & 0.7 & 0.7 & 0.7 \\
\hline Labor market experience (years) & 13.2 & 13.6 & 7.2 \\
\hline Male & $52.5 \%$ & $51.3 \%$ & $72.2 \%$ \\
\hline Married & $55.1 \%$ & $54.1 \%$ & $71.4 \%$ \\
\hline Primary and secondary education & $41.8 \%$ & $41.8 \%$ & $42.7 \%$ \\
\hline Vocational education & $41.8 \%$ & $41.6 \%$ & $44.1 \%$ \\
\hline Tertiary education & $16.4 \%$ & $16.6 \%$ & $13.2 \%$ \\
\hline \multicolumn{4}{|l|}{ Taxable Income: } \\
\hline Labor Income & 247,935 & 249,328 & 226,275 \\
\hline Other personal income & 3,204 & 737 & 41,554 \\
\hline Capital income & $-27,585$ & $-27,760$ & $-24,853$ \\
\hline Deductions & 16,056 & 16,490 & 9,299 \\
\hline \multicolumn{4}{|c|}{ Share of Taxpayers Close to Kink Points: } \\
\hline Top kink & $2.39 \%$ & $2.01 \%$ & $8.37 \%$ \\
\hline Middle kink & $2.36 \%$ & $2.40 \%$ & $1.74 \%$ \\
\hline Bottom kink & $1.20 \%$ & $1.04 \%$ & $3.78 \%$ \\
\hline Number of observations & $37,599,492$ & $35,326,867$ & $2,272,625$ \\
\hline
\end{tabular}

Notes: Table entries are means unless otherwise noted. All monetary values are in real 2005 Danish Kroner (DKK), where 1 USD $=5.3$ DKK as of July 2011. Taxpayers close to kink points are defined as those who have an income within a range of 5,000 DKK of the top kink, 3,000 DKK of the middle kink and 2,000 DKK of the bottom kink. 
Table 4. The Elasticity of Labor Income

\begin{tabular}{|c|c|c|c|c|c|c|c|c|}
\hline \multirow[b]{2}{*}{$\begin{array}{l}\text { Taxpayers around kinks: } \\
\text { Broad income restriction: }\end{array}$} & \multicolumn{4}{|c|}{ Panel A. Wage Earners } & \multicolumn{4}{|c|}{ Panel B. Self-Employed } \\
\hline & $\begin{array}{c}\text { Include } \\
>0 k \\
(1)\end{array}$ & $\begin{array}{c}\text { Include } \\
>50 k \\
(2)\end{array}$ & $\begin{array}{c}\text { Include } \\
>100 \mathrm{k} \\
(3)\end{array}$ & $\begin{array}{c}\text { Exclude } \\
>0 \mathrm{k} \\
(4)\end{array}$ & $\begin{array}{c}\text { Include } \\
>0 \mathrm{k} \\
(5)\end{array}$ & $\begin{array}{c}\text { Include } \\
>50 \mathrm{k} \\
(6)\end{array}$ & $\begin{array}{c}\text { Include } \\
>100 \mathrm{k} \\
(7)\end{array}$ & $\begin{array}{c}\text { Exclude } \\
>0 \mathrm{k} \\
\text { (8) }\end{array}$ \\
\hline No pre-reform income controls & $\begin{array}{c}-0.191^{* * *} \\
(0.002)\end{array}$ & $\begin{array}{c}-0.123^{* * *} \\
(0.002)\end{array}$ & $\begin{array}{c}-0.102 * * * \\
(0.002)\end{array}$ & $\begin{array}{c}-0.132 * * * \\
(0.002)\end{array}$ & $\begin{array}{c}-0.155^{* * *} \\
(0.013)\end{array}$ & $\begin{array}{c}-0.141 * * * \\
(0.014)\end{array}$ & $\begin{array}{c}-0.126 * * * \\
(0.015)\end{array}$ & $\begin{array}{c}-0.162 * * * \\
(0.015)\end{array}$ \\
\hline Log base-year (period s) income & $\begin{array}{c}0.060 * * * \\
(0.002)\end{array}$ & $\begin{array}{c}0.067^{* * *} \\
(0.002)\end{array}$ & $\begin{array}{c}0.065^{* * *} \\
(0.002)\end{array}$ & $\begin{array}{c}0.062 * * * \\
(0.002)\end{array}$ & $\begin{array}{c}0.095^{* * *} \\
(0.015)\end{array}$ & $\begin{array}{c}0.088^{* * *} \\
(0.015)\end{array}$ & $\begin{array}{c}0.085^{* * *} \\
(0.016)\end{array}$ & $\begin{array}{c}0.098 * * * \\
(0.016)\end{array}$ \\
\hline Splines of log base-year (period s) income & $\begin{array}{c}0.042^{* * *} \\
(0.002)\end{array}$ & $\begin{array}{c}0.042 * * * \\
(0.002)\end{array}$ & $\begin{array}{c}0.044 * * * \\
(0.002)\end{array}$ & $\begin{array}{c}0.043 * * * \\
(0.002)\end{array}$ & $\begin{array}{c}0.100 * * * \\
(0.013)\end{array}$ & $\begin{array}{c}0.096 * * * \\
(0.014)\end{array}$ & $\begin{array}{c}0.093 * * * \\
(0.014)\end{array}$ & $\begin{array}{c}0.101 * * * \\
(0.015)\end{array}$ \\
\hline $\begin{array}{l}\text { Splines of log s-1 income and log deviation between s-1 } \\
\text { and s incomes }\end{array}$ & $\begin{array}{c}0.046 * * * \\
(0.002)\end{array}$ & $\begin{array}{l}0.051 * * * \\
(0.002)\end{array}$ & $\begin{array}{c}0.052 * * * \\
(0.002)\end{array}$ & $\begin{array}{c}0.047^{* * *} \\
(0.002)\end{array}$ & $\begin{array}{c}0.090 * * * \\
(0.014)\end{array}$ & $\begin{array}{c}0.083 * * * \\
(0.015)\end{array}$ & $\begin{array}{c}0.081^{* * *} \\
(0.015)\end{array}$ & $\begin{array}{c}0.094 * * * \\
(0.016)\end{array}$ \\
\hline $\begin{array}{l}\text { Splines of log s-1 income and splines of log deviation } \\
\text { between s-1 and s incomes }\end{array}$ & $\begin{array}{c}0.042^{* * *} \\
(0.002)\end{array}$ & $\begin{array}{c}0.046 * * * \\
(0.002)\end{array}$ & $\begin{array}{c}0.047^{* * *} \\
(0.002)\end{array}$ & $\begin{array}{c}0.045^{* * *} \\
(0.002)\end{array}$ & $\begin{array}{c}0.087^{* * *} \\
(0.014)\end{array}$ & $\begin{array}{c}0.081^{* * *} \\
(0.015)\end{array}$ & $\begin{array}{c}0.078 * * * \\
(0.015)\end{array}$ & $\begin{array}{c}0.093^{* * *} \\
(0.017)\end{array}$ \\
\hline $\begin{array}{l}\text { Splines of log s- } 2 \text { income and log deviations between s-2 } \\
\text { and s-1 incomes and between s-1 and s incomes }\end{array}$ & $\begin{array}{c}0.056 * * * \\
(0.002)\end{array}$ & $\begin{array}{c}0.062 * * * \\
(0.002)\end{array}$ & $\begin{array}{c}0.061^{* * *} \\
(0.002)\end{array}$ & $\begin{array}{c}0.055^{* * *} \\
(0.002)\end{array}$ & $\begin{array}{c}0.098 * * * \\
(0.015)\end{array}$ & $\begin{array}{c}0.093 * * * \\
(0.015)\end{array}$ & $\begin{array}{c}0.090 * * * \\
(0.015)\end{array}$ & $\begin{array}{c}0.101^{* * *} \\
(0.017)\end{array}$ \\
\hline Number of observations & $29,568,870$ & $28,630,140$ & $27,121,055$ & $28,060,857$ & $1,646,270$ & $1,568,195$ & $1,381,560$ & $1,405,915$ \\
\hline
\end{tabular}

Notes: The table shows elasticity estimates based on 2 SLS regressions, where standard errors (shown in parentheses) are clustered by individual. $*=$ significant at the $10 \%$ level, $* *=$ significant at the $5 \%$ level, and ${ }^{* * *}=$ significant at the $1 \%$ level. The dependent variable in all specifications is the three-year growth rate in real wage earnings. The independent variable of interest is the three-year growth rate in the marginal net-of-tax rate, instrumented using the three-year growth rate in the simulated marginal net-of-tax rate under baseyear behavior (i.e., mechanical tax variation from tax reforms). All elasticities in the table are based on specifications without income effects. All specifications include controls for labor market experience, age, gender, marital status, kids, place of residence, educational attainment, industry, local unemployment rate, and year fixed effects. Regressions are weighted by labor income and restricts the sample to individuals with positive labor income (in addition to the sample restrictions described in section 3 ). "Splines" refer to a flexible piecewise linear functional form with 10 components. Taxpayers close to kink points are defined as those who have an income within a range of 5,000 DKK of the top kink, 3,000 DKK of the middle kink and 2,000 DKK of the bottom kink. 
Table 5. The Elasticity of Labor Income: Compensated vs. Uncompensated Elasticity

\begin{tabular}{|c|c|c|c|c|c|c|}
\hline \multirow[b]{4}{*}{ Pre-reform income controls } & \multicolumn{3}{|c|}{ Panel A. Wage Earners } & \multicolumn{3}{|c|}{ Panel B. Self-Employed } \\
\hline & \multirow{2}{*}{$\begin{array}{c}\begin{array}{c}\text { Without income } \\
\text { effect }\end{array} \\
\begin{array}{c}\text { Compensated } \\
\text { elasticity }\end{array}\end{array}$} & \multicolumn{2}{|c|}{ With income effect } & \multirow{3}{*}{$\begin{array}{c}\text { Without income } \\
\text { effect } \\
\begin{array}{c}\text { Compensated } \\
\text { elasticity } \\
\text { (4) }\end{array}\end{array}$} & \multicolumn{2}{|c|}{ With income effect } \\
\hline & & $\begin{array}{c}\text { Uncompensated } \\
\text { elasticity }\end{array}$ & Income Elasticity & & $\begin{array}{c}\text { Uncompensated } \\
\text { elasticity }\end{array}$ & Income Elasticity \\
\hline & (1) & $(2)$ & (3) & & (5) & (6) \\
\hline \multirow{2}{*}{ No pre-reform income controls } & $-0.191 * * *$ & $-0.140 * * *$ & $-0,007 * * *$ & $-0.155^{* * *}$ & $-0.159 * * *$ & -0.003 \\
\hline & $(0.002)$ & $(0.003)$ & $(0.002)$ & $(0.013)$ & $(0.030)$ & $(0.021)$ \\
\hline \multirow{2}{*}{ Log base-year (period s) income } & $0.060 * * *$ & $0.042^{* * *}$ & $-0.015 * * *$ & $0.095^{* * *}$ & $0.114^{* * *}$ & -0.015 \\
\hline & $(0.002)$ & $(0.003)$ & $(0.003)$ & $(0.015)$ & $(0.033)$ & $(0.021)$ \\
\hline \multirow{2}{*}{ Splines of log base-year (periods) income } & $0.042 * * *$ & $0.034 * * *$ & $-0.007 * * *$ & $0.100 * * *$ & $0.105^{* * *}$ & -0.004 \\
\hline & $(0.002)$ & $(0.003)$ & $(0.003)$ & $(0.013)$ & $(0.032)$ & $(0.021)$ \\
\hline \multirow{2}{*}{$\begin{array}{l}\text { Splines of log s-1 income and log deviation between s-1 } \\
\text { and s incomes }\end{array}$} & $0.046 * * *$ & $0,030 * * *$ & $-0.013 * * *$ & $0.090 * * *$ & $0.096 * * *$ & -0.005 \\
\hline & $(0.002)$ & $(0.003)$ & $(0.002)$ & $(0.014)$ & $(0.032)$ & $(0.021)$ \\
\hline \multirow{2}{*}{$\begin{array}{l}\text { Splines of log s-1 income and splines of log deviation } \\
\text { between s- } 1 \text { and s incomes }\end{array}$} & $0.042 * * *$ & $0.030 * * *$ & $-0.011 * * *$ & $0.087^{* * *}$ & $0.093 * * *$ & -0.004 \\
\hline & $(0.002)$ & $(0.003)$ & $(0.002)$ & $(0.014)$ & $(0.032)$ & $(0.021)$ \\
\hline \multirow{2}{*}{$\begin{array}{l}\text { Splines of log s- } 2 \text { income and log deviations between s-2 } \\
\text { and s-1 incomes and between s-1 and s incomes }\end{array}$} & $0.056 * * *$ & $0.034 * * *$ & $-0.019 * * *$ & $0.098 * * *$ & $0.096 * * *$ & -0.001 \\
\hline & $(0.002)$ & $(0.003)$ & $(0.002)$ & $(0.015)$ & $(0.030)$ & $(0.020)$ \\
\hline Number of observations & & $29,568,870$ & & & $1,646,270$ & \\
\hline
\end{tabular}

Notes: The table shows elasticity estimates based on 2 SLS regressions, where standard errors (shown in parentheses) are clustered by individual. $*=$ significant at the $10 \%$ level, $* *=$ significant at the $5 \%$ level, and ${ }^{* * *}=$ significant at the $1 \%$ level. Columns (1) and (4) repeat results from Table 4 based on a specification without income effect, while the other columns consider a specification with income effects. The dependent variable in all specifications is the three-year growth rate in real wage earnings. The independent variables of interest are three-year growth rates in the marginal net-of-tax rate and virtual income, instrumented using mechanical variation in those variables created by tax reforms. All specifications include controls for labor market experience, age, gender, marital status, kids, place of residence, educational attainment, industry, local unemployment rate, and year fixed effects. Regressions are weighted by labor income and restricts the sample to individuals with positive labor income (in addition to the sample restrictions described in section 3). "Splines" refer to a flexible piecewise linear functional form with 10 components. 
Table 6. Elasticities of Capital Income vs. Labor Income

\begin{tabular}{|c|c|c|c|}
\hline Pre-reform income controls & $\begin{array}{l}\text { Labor income } \\
\text { (1) }\end{array}$ & $\begin{array}{l}\text { Negative capital income } \\
\text { (2) }\end{array}$ & $\begin{array}{l}\text { Positive capital income } \\
\text { (3) }\end{array}$ \\
\hline Log base-year (period s) income & $\begin{array}{c}0.060 * * * \\
(0.002)\end{array}$ & $\begin{array}{c}-0.103^{* * *} \\
(0.007)\end{array}$ & $\begin{array}{c}0.106 * * * \\
(0.024)\end{array}$ \\
\hline $\begin{array}{l}\text { Splines of log s-1 income and log deviation between s-1 } \\
\text { and s incomes }\end{array}$ & $\begin{array}{c}0.049 * * * \\
(0.002)\end{array}$ & $\begin{array}{c}-0.120 * * * \\
(0.005)\end{array}$ & $\begin{array}{c}0.113^{* * *} \\
(0.024)\end{array}$ \\
\hline $\begin{array}{l}\text { Splines of log s-1 income and splines of log deviation } \\
\text { between s-1 and s incomes }\end{array}$ & $\begin{array}{c}0.046 * * * \\
(0.002)\end{array}$ & $\begin{array}{c}-0.117^{* * *} \\
(0.005)\end{array}$ & $\begin{array}{c}0.125^{* * *} \\
(0.024)\end{array}$ \\
\hline
\end{tabular}

Notes: The table shows elasticity estimates based on 2SLS regressions, where standard errors (shown in parentheses) are clustered by individual. ${ }^{*}=$ significant at the $10 \%$ level, ${ }^{* *}=$ significant at the $5 \%$ level, and ${ }^{* * *}=$ significant at the $1 \%$ level. The dependent variable is real labor income in column (1), negative capital capital income in absolute value in column (2), and positive capital income in column (3). The independent variable of interest is the three-year growth rate in the marginal net-of-tax rate on labor income in column (1), negative capital income in column (2) and positive capital income in column (3), each instrumented using the three-year growth rate in the simulated marginal net-of-tax rate under base-year behavior. All elasticities are based on specifications without income effects and without cross-effects between labor and capital income. All specifications include controls for labor market experience, age, gender, marital status, kids, place of residence, educational attainment, industry, local unemployment rate, and year fixed effects. Regressions are weighted by income (labor income in column (1), capital income in columns (2)-(3)). Labor income regressions restrict the sample to individuals with positive labor income, while capital income regressions drop individuals with zero capital income and individuals whose capital income changes sign between base and post year (in addition to the basic sample restrictions described in section 3). "Splines" refer to a flexible piecewise linear functional form with 10 components. 
Table 7. Labor and Capital Income Elasticities: Small vs. Large Reforms

\begin{tabular}{|c|c|c|c|c|c|c|}
\hline \multirow[b]{3}{*}{ Pre-reform income controls } & \multicolumn{3}{|c|}{ Panel A. Labor income } & \multicolumn{3}{|c|}{ Panel B. Positive capital income } \\
\hline & $\begin{array}{l}\text { All reforms } \\
(1984-2005)\end{array}$ & $\begin{array}{l}1987 \text { reform } \\
(1984-1990)\end{array}$ & $\begin{array}{l}\text { Post-1987 reforms } \\
\text { (1991-2005) }\end{array}$ & $\begin{array}{l}\text { All reforms } \\
(1984-2005)\end{array}$ & $\begin{array}{l}1987 \text { reform } \\
(1984-1990)\end{array}$ & $\begin{array}{l}\text { Post-1987 reforms } \\
\text { (1991-2005) }\end{array}$ \\
\hline & $(1)$ & $(2)$ & (3) & (4) & $(5)$ & $(6)$ \\
\hline No pre-reform income controls & $\begin{array}{c}-0.189 * * * \\
(0.002)\end{array}$ & $\begin{array}{c}-0.182 * * * \\
(0.002)\end{array}$ & $\begin{array}{c}-0.192 * * * \\
(0.004)\end{array}$ & $\begin{array}{c}0.081 * * * \\
(0.024)\end{array}$ & $\begin{array}{c}0.131 * * * \\
(0.021)\end{array}$ & $\begin{array}{c}0.124 * * * \\
(0.032)\end{array}$ \\
\hline Log base-year (period s) income & $\begin{array}{c}0.060 * * * \\
(0.002)\end{array}$ & $\begin{array}{c}0.112 * * * \\
(0.002)\end{array}$ & $\begin{array}{c}0.043 * * * \\
(0.004)\end{array}$ & $\begin{array}{c}0.106 * * * \\
(0.024)\end{array}$ & $\begin{array}{c}0.137 * * * \\
(0.023)\end{array}$ & $\begin{array}{c}0.076 * * \\
(0.032)\end{array}$ \\
\hline Splines of log base-year (period s) income & $\begin{array}{c}0.044 * * * \\
(0.002)\end{array}$ & $\begin{array}{c}0.104 * * * \\
(0.002)\end{array}$ & $\begin{array}{c}0.023 * * * \\
(0.004)\end{array}$ & $\begin{array}{c}0.135^{* * *} \\
(0.025)\end{array}$ & $\begin{array}{c}0.151^{* * *} \\
(0.024)\end{array}$ & $\begin{array}{c}0.109 * * * \\
(0.035)\end{array}$ \\
\hline $\begin{array}{l}\text { Splines of log s-1 income and log deviation between s-1 } \\
\text { and s incomes }\end{array}$ & $\begin{array}{c}0.049 * * * \\
(0.002)\end{array}$ & $\begin{array}{c}0.111^{* * *} \\
(0.002)\end{array}$ & $\begin{array}{c}0.025^{* * *} \\
(0.004)\end{array}$ & $\begin{array}{c}0.113^{* * *} \\
(0.024)\end{array}$ & $\begin{array}{c}0.155^{* * *} \\
(0.023)\end{array}$ & $\begin{array}{c}0.094^{* * *} \\
(0.032)\end{array}$ \\
\hline $\begin{array}{l}\text { Splines of log s- } 1 \text { income and splines of log deviation } \\
\text { between s- } 1 \text { and s incomes }\end{array}$ & $\begin{array}{c}0.046 * * * \\
(0.002)\end{array}$ & $\begin{array}{c}0.115^{* * *} \\
(0.002)\end{array}$ & $\begin{array}{l}0.018 * * * \\
(0.004)\end{array}$ & $\begin{array}{c}0.125^{* * *} \\
(0.024)\end{array}$ & $\begin{array}{c}0.153 * * * \\
(0.023)\end{array}$ & $\begin{array}{c}0.091 * * * \\
(0.031)\end{array}$ \\
\hline $\begin{array}{l}\text { Splines of log s- } 2 \text { income and log deviations between s-2 } \\
\text { and s-1 incomes and between s- } 1 \text { and s incomes }\end{array}$ & $\begin{array}{c}0.058^{* * *} \\
(0.002)\end{array}$ & $\begin{array}{c}0.122 * * * \\
(0.002)\end{array}$ & $\begin{array}{c}0.034 * * * \\
(0.004)\end{array}$ & $\begin{array}{c}0.097 * * * \\
(0.024)\end{array}$ & $\begin{array}{c}0.157 * * * \\
(0.023)\end{array}$ & $\begin{array}{c}0.084^{* * *} \\
(0.028)\end{array}$ \\
\hline Number of observations & $31,215,140$ & $11,799,628$ & $19,415,512$ & $4,837,538$ & $1,756,743$ & $3,080,795$ \\
\hline
\end{tabular}

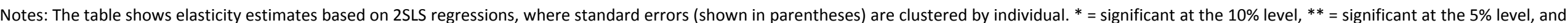

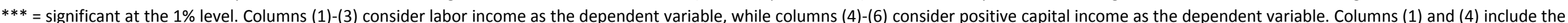

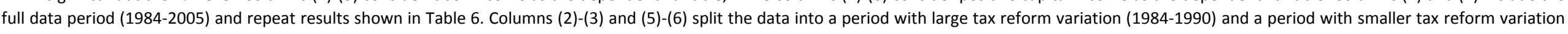
(1991-2005). All specifications are otherwise identical to those described in Table 6 . 
Table 8. Labor Income Elasticities: Own-Tax Effect and Cross-Tax Effect with Capital Income

\begin{tabular}{|c|c|c|c|c|c|c|}
\hline \multirow[b]{2}{*}{ Pre-reform income controls } & \multicolumn{2}{|c|}{ Panel A. All Individuals } & \multicolumn{2}{|c|}{ Panel B. Wage earners } & \multicolumn{2}{|c|}{ Panel C. Self-employed } \\
\hline & $\begin{array}{l}\text { Own-tax } \\
\text { elasticity } \\
\text { (1) }\end{array}$ & $\begin{array}{c}\text { Cross-tax } \\
\text { elasticity } \\
\text { (2) }\end{array}$ & $\begin{array}{l}\text { Own-tax } \\
\text { elasticity } \\
\text { (3) }\end{array}$ & $\begin{array}{c}\text { Cross-tax } \\
\text { elasticity } \\
\text { (4) }\end{array}$ & $\begin{array}{l}\text { Own-tax } \\
\text { elasticity } \\
\text { (5) }\end{array}$ & $\begin{array}{c}\text { Cross-tax } \\
\text { elasticity } \\
\text { (6) }\end{array}$ \\
\hline No pre-reform income controls & $\begin{array}{c}-0.114^{* * *} \\
(0.003)\end{array}$ & $\begin{array}{c}-0.099 * * * \\
(0.002)\end{array}$ & $\begin{array}{c}-0.112^{* * *} \\
(0.003)\end{array}$ & $\begin{array}{c}-0.010^{* * *} \\
(0.002)\end{array}$ & $\begin{array}{c}-0.141^{* * *} \\
(0.031)\end{array}$ & $\begin{array}{c}-0.092^{* * *} \\
(0.029)\end{array}$ \\
\hline Log base-year (period s) income & $\begin{array}{c}0.065^{* * *} \\
(0.002)\end{array}$ & $\begin{array}{c}0.003 \\
(0.002)\end{array}$ & $\begin{array}{c}0.062^{* * *} \\
(0.003)\end{array}$ & $\begin{array}{l}0.003^{*} \\
(0.002)\end{array}$ & $\begin{array}{c}0.116^{* * *} \\
(0.035)\end{array}$ & $\begin{array}{l}-0.018 \\
(0.024)\end{array}$ \\
\hline Splines of log base-year (period s) income & $\begin{array}{c}0.049 * * * \\
(0.003)\end{array}$ & $\begin{array}{c}0.004^{* * *} \\
(0.002)\end{array}$ & $\begin{array}{c}0.047 * * * \\
(0.002)\end{array}$ & $\begin{array}{c}0.004^{* * *} \\
(0.001)\end{array}$ & $\begin{array}{c}0.086^{* *} \\
(0.040)\end{array}$ & $\begin{array}{l}-0.022 \\
(0.026)\end{array}$ \\
\hline $\begin{array}{l}\text { Splines of log s-1 income and log deviation between s-1 } \\
\text { and s incomes }\end{array}$ & $\begin{array}{c}0.056^{* * *} \\
(0.003)\end{array}$ & $\begin{array}{c}0.004^{* * *} \\
(0.002)\end{array}$ & $\begin{array}{c}0.053^{* * *} \\
(0.003)\end{array}$ & $\begin{array}{c}0.005^{* * *} \\
(0.002)\end{array}$ & $\begin{array}{c}0.111^{* * *} \\
(0.031)\end{array}$ & $\begin{array}{l}-0.036 \\
(0.029)\end{array}$ \\
\hline $\begin{array}{l}\text { Splines of log s- } 1 \text { income and splines of log deviation } \\
\text { between s-1 and s incomes }\end{array}$ & $\begin{array}{c}0.064^{* * *} \\
(0.003)\end{array}$ & $\begin{array}{c}0.006 * * * \\
(0.002)\end{array}$ & $\begin{array}{c}0.062^{* * *} \\
(0.003)\end{array}$ & $\begin{array}{c}0.007^{* * *} \\
(0.002)\end{array}$ & $\begin{array}{c}0.101^{* * *} \\
(0.037)\end{array}$ & $\begin{array}{l}-0.041 \\
(0.028)\end{array}$ \\
\hline $\begin{array}{l}\text { Splines of log s-2 income and log deviations between s-2 } \\
\text { and s-1 incomes and between s-1 and s incomes }\end{array}$ & $\begin{array}{c}0.067^{* * *} \\
(0.003)\end{array}$ & $\begin{array}{l}0.003^{*} \\
(0.002)\end{array}$ & $\begin{array}{c}0.064^{* * *} \\
(0.003)\end{array}$ & $\begin{array}{c}0.005^{* * *} \\
(0.002)\end{array}$ & $\begin{array}{c}0.121^{* * *} \\
(0.038)\end{array}$ & $\begin{array}{l}-0.033 \\
(0.031)\end{array}$ \\
\hline Number of observations & \multicolumn{2}{|c|}{$31,158,640$} & \multicolumn{2}{|c|}{$29,538,050$} & \multicolumn{2}{|c|}{$1,620,590$} \\
\hline
\end{tabular}

Notes: The table shows elasticity estimates based on 2 SLS regressions, where standard errors (shown in parentheses) are clustered by individual. ${ }^{*}=$ significant at the $10 \%$ level, ${ }^{* *}=$ significant at the $5 \%$ level, and ${ }^{* * *}=$ significant at the $1 \%$ level. The dependent variable in all regressions is the three-year growth rate in real wage earnings. The independent variables of interest are the three-year growth rate in the marginal net-of-tax rate on labor income (own-tax effect) and the three-year growth rate in the marginal net-of-tax rate on capital income (cross-tax effect). Both of these marginal net-of-tax rates are instrumented using threeyear growth rates in simulated marginal net-of-tax rates under base-year behavior. All elasticities in the table are based on specifications without income effects. Regressions include taxpayers with non-zero capital income (positive or negative), and are otherwise based on the same sample restrictions and include the same controls as the previous specifications for labor income (as in Tables 4, 6, and 7). 